\title{
Chemical and Biological Sensors for Time-Series Research: Current Status and New Directions
}

\author{
A UTHORS \\ Kendra L. Daly \\ Robert H. Byrne \\ College of Marine Science, \\ University of South Florida
}

Andrew G. Dickson

Scripps Institution of Oceanography,

University of California, San Diego

Scott M. Gallager

Woods Hole Oceanographic Institution

Mary Jane Perry

Darling Marine Center, University of Maine

Margaret K. Tivey

Woods Hole Oceanographic Institution

\section{N TRO D U C TIO N}

\begin{abstract}
echnological advances have often led to major improvements in our understanding of ocean phenomena. Despite the fact that the oceans cover more than $70 \%$ of our planet and have a profound impact on global climate, weather patterns, human health, agriculture, and commerce, our ability to make sustained measurements of ocean processes is limited and much of the oceans remain largely unexplored. The National Science Foundation's Ocean Observatories Initiative, through the Ocean Research Interactive Observatory Networks (ORION) Program, will establish a network of seafloor observatories linked by fiber-optic/power cables, as well as permanent and relocatable moorings in coastal regions and relocatable deep-sea moorings. Along the continental United States the ORION infrastructure will be coupled with the National Ocean Partnership Program's Integrated Ocean Observing System (IOOS). These combined systems will permit unprecedented high-frequency, in situ measurements of dynamic physical, chemical, and biological properties that occur over varying temporal and spatial scales. This new approach will require
\end{abstract}

\section{A B S T R A C T}

Ocean observatories will require extensive use of sensors and sensing systems to enable time-series observations and interactive experiments on remote permanent and mobile platforms. In this paper we assess the "readiness" of chemical and biological sensors that will be critical to the success of ocean observatories. We conclude that although there have been many technological advances in the development of sensors in recent years, few chemical or biological sensors are capable of longterm deployment ( 1 year). In particular, sensors in coastal regions and near hydrothermal vents will need to be regularly serviced for biofouling for the foreseeable future, while sensors on deep-water observatories that spend limited time in the euphotic zone may be able to operate for longer periods. A number of exciting new technologies hold great promise for sensors in the years to come. Significant effort and resources, however, are urgently needed for sensor development to ensure that the opportunities for science and discovery made accessible by ocean observatories are fully realized.

extensive sensing systems on permanent and mobile platforms to enable real-time interactive observations and experiments of the earth-ocean-atmosphere systems.

Numerous workshops (Daly, 2000; Seyfried et al., 2000; Glenn and Dickey, 2003; Jahnke, 2003; Rudnik and Perry, 2003; Gallager and Whelan, 2004) and a National Research Council (2003) report have identified compelling science questions that require time-series observations and the sensors needed to address those issues. Examples of high-priority sensors include: oxygen, nitrate, ammonium, urea, silica, phosphate, $\mathrm{pH}$, total inorganic carbon, $\mathrm{pCO}_{2}$, alkalinity, dissolved and particulate organic carbon and nitrogen, methane, hydrogen sulfide, dissolved halogens, iron species, magnesium, hydrogen, and microbial activity. Mass spectrometers are highly desirable sensors because they can simultaneously detect a wide variety of the species listed above. Acoustic and optical sensors are needed to measure a variety of physical, chemical, and biological phenomena, such as physical microstructure, microbial activity, phytoplankton and zooplankton species identification, abundance, properties, and physiological rates, and fish biomass and distribution. The reader should refer to these reports for discussions of critical issues and recommendations for sensor development that are beyond the scope of this paper.

Here we assess the current status of "readiness" of different types of chemical and biological sensors that will be crucial to the success of ocean observatories (Tables 1-7). Sensors are categorized by developmental stage and deployment capability to highlight where additional efforts are urgently needed to ensure that essential sensors will be capable of long-term deployment during the initial stages of the observatory initiative. This is especially important given the difficult challenges and long development time (up to 10 years) for new sensors. Some privately held sensors that have been deployed for extended periods have better documentation of performance than those commercially available, so that reliability of available instruments cannot be easily assessed. Continued development of sensing systems also will be vital to realizing the full potential of the observatories. Please note that the sensors listed herein are not an inclusive list and endorsement is not intended over 
other available products. Due to page limitations many excellent sensors could not be described. Lastly we highlight some examples of exciting new directions for sensors and sensing systems that may be available for use in years to come.

\section{Oxygen Sensors}

The oxygen concentration in marine systems is essentially dependent on three main processes: gas exchange with the atmosphere (solubility equilibrium), mixing of waters away from the surface, and biological changes in oxygen levels (production of oxygen through photosynthesis and consumption of oxygen in oxidative microbial processes). High-quality in situ sensors are thus essential to monitoring such processes effectively. Ideally these sensors would have a fast response, be very sensitive to changes in the oxygen concentration, and be stable for long time periods even in highly productive waters. Unfortunately, no such paragon exists!

A relatively recent review of methods of seawater analysis (Graßhoffet al., 1999) states: "Nearly all sensors used for in situ registration of dissolved oxygen in seawater are of the amperometric membrane covered electrode type introduced by Clark et al. (1953)." Although this is no longer true as other analytical approaches now exist (Table 1), the Clark-type design is still perhaps the most widely used. In this design, oxygen passes through a gas-permeable membrane into an inner compartment where it is reduced cathodically at a polarized electrode. The sensor current thus depends on the oxygen concentration outside the membrane, and the rate of diffusion through the membrane and the inner electrolyte. A number of problems have been reported with such sensors, particularly dynamic errors occurring when they are used in a profiling mode, i.e., subject to rapid changes of temperature and pressure. This has led to various refinements.

A significant improvement, proposed by Dr. Chris Langdon (Lamont Doherty Earth Observatory, Columbia University) and adopted in instruments from YSI Environmental, was to pulse the polarizing potential applied to the cathode every few minutes. It is off during the rest of the time, so the oxygen levels inside the membrane can recover. This makes the method more or less flow independent, and reduces most of the effects that are membrane dependant. There are many benefits, such as a longer period between calibrations, less oxygen consumed, flow rate dependency removed, and the repeatability of measurements improves by an order of magnitude. However, the response time suffers as a result. This approach has been used on drifting floats (e.g., those used in the Atlantic Climate Change Experiment), and a second generation of this design has been used recently on moorings (e.g., Emerson et al., 2002; and on the O-SCOPE mooring at Station $P$ in the North Pacific).

Another approach (Atkinson et al., 1995), which has been tested though not developed commercially, does away with the membrane completely and uses the seawater itself as the electrolyte together with a micro-hole to create reproducible diffusion conditions. A related method (Gundersen et al., 1998) uses a miniature

\section{TABLE 1}

Current status of oxygen sensors. Development stages are I: Sensor currently operational and commercially available; II: Sensor successfully deployed in marine environment for $>1$ month with consistent results but not commercially available; III: Mature development, transition to long-term deployment in progress; IV: Mature development, potential for transition; V: Early stage of development with successful short-term deployments in seawater; VI: Bench-top prototype in operation. Power (based on available information; watts, W, or amps, A) is consumption during operation. Sensor response time is in seconds (s), minutes ( $\mathrm{min})$, or hours. The sensors deployment capability is shown for moorings (M), drifters $(D)$, glider $(G)$, autonomous vehicles $(A)$, profiling $(\mathrm{P})$, towed vehicle $(\mathrm{T})$, ROV or HOV $(\mathrm{R})$, and shipboard $(\mathrm{S})$

\begin{tabular}{|c|c|c|c|c|c|}
\hline Sensor & $\begin{array}{l}\text { Development } \\
\text { stage }\end{array}$ & Power & $\begin{array}{l}\text { Response } \\
\text { time }^{\dagger}\end{array}$ & $\begin{array}{l}\text { Deployment } \\
\text { capability }\end{array}$ & $\begin{array}{l}\text { Source/ } \\
\text { contact }\end{array}$ \\
\hline $\begin{array}{l}\text { Pulsed Clark-type } \\
\text { oxygen sensor }\end{array}$ & III & $\begin{array}{l}4-9 \mathrm{~mA} \\
\text { ( } 12 \mathrm{VDC}^{*}\end{array}$ & $\sim 60 \mathrm{~s}$ & $\mathrm{M}, \mathrm{D}$ & $\begin{array}{l}\text { CLangdon, LDEO } \\
\text { langdon@|deo.columbia.edu }\end{array}$ \\
\hline $\begin{array}{l}\text { Rapid-Pulse }{ }^{T M} \\
\text { Clark-type } \\
\text { oxygen sensor }\end{array}$ & I & $\psi$ & $\sim 60 \mathrm{~s}$ & $\mathrm{M}, \mathrm{P}(200 \mathrm{~m})$ & $\begin{array}{l}\text { YSI Environmental } \\
\text { www.ysi.com }\end{array}$ \\
\hline $\begin{array}{l}\text { Micro Clark-type } \\
\text { (non-pulsed) }\end{array}$ & III & $2 \mathrm{~mA}$ & $<1 \mathrm{~s}$ & $P$ & $\begin{array}{l}\text { Unisense } \\
\text { www.unisense.com }\end{array}$ \\
\hline $\begin{array}{l}\text { SBE } 43 \text { Clark-type } \\
\text { (non-pulsed) }\end{array}$ & I & $60 \mathrm{~mW}$ & $\sim 15 \mathrm{~s}$ & $\mathrm{P}, \mathrm{M}$ & $\begin{array}{l}\text { Sea-Bird Electronics, Inc. } \\
\text { www.seabird.com }\end{array}$ \\
\hline $\begin{array}{l}\text { FOXY Fiber Optic } \\
\text { Oxygen Sensor }\end{array}$ & I & $150 \mathrm{~mA}$ & $\sim 30 \mathrm{~s}$ & M & $\begin{array}{l}\text { Ocean Optics } \\
\text { www.oceanoptics.com }\end{array}$ \\
\hline $\begin{array}{l}\text { Planar Oxygen } \\
\text { Sensor Spots }\end{array}$ & I & $6.6 \mathrm{~W}$ & $\sim 30 \mathrm{~s}$ & & $\begin{array}{l}\text { PreSens } \\
\text { www.presens.de }\end{array}$ \\
\hline Oxygen Optode & I & $80 \mathrm{~mA}$ & $\sim 30 \mathrm{~s}$ & $\mathrm{P}, \mathrm{M}$ & $\begin{array}{l}\text { Aanderaa } \\
\text { www.aanderaa.com }\end{array}$ \\
\hline $\begin{array}{l}\text { Gas Tension } \\
\text { Device PSI-02 Pro }\end{array}$ & I & $0.8 \mathrm{~W}$ & hours & M & $\begin{array}{l}\text { Pro-Oceanus } \\
\text { www.pro-oceanus.com }\end{array}$ \\
\hline
\end{tabular}

tDepends, in part, on temperature. $\quad{ }^{*}$ Assumes sampling rate of once per hour or every $5 \mathrm{~min}$. ${ }^{\mathrm{y}}$ Can only be deployed in a YSI sonde system. 
equations are daunting (e.g., Owens and Millard, 1985; Atkinson et al., 1996).

An alternate analytical approach to sensing dissolved oxygen depends on the ability of oxygen as a triplet molecule to efficiently quench the fluorescence of certain luminophores, an effect called "dynamic fluorescence quenching." Collision of an oxygen molecule with a fluorophore in its excited state leads to a non-radiative transfer of energy. The degree of fluorescence quenching relates to the frequency of collisions, and thus to the concentration, pressure, and temperature of the oxygen-containing media. There are a variety of approaches to monitoring this effect: either monitoring the intensity of the fluorescence itself, or monitoring the fluorescence lifetime, or monitoring the phase-shift of the emitted light.

The simplest of these approaches is to simply monitor the intensity of the fluorescence itself, relating the degree of quenching to the oxygen concentration. The earliest optodes used in marine systems were based on this approach and, indeed, it appears that the FOXY fiberoptic oxygen sensor (available from Ocean Optics, Dunedin, FL) employs a similar intensity-based technique. Wang et al. (1999) reported results from using this sensor to monitor oxygen changes in an estuarine environment. The calibration of such an intensity-based detection scheme, however, can drift due to degradation of the chromophore with time. Consequently, other manufacturers have incorporated either a lifetime-based detection scheme (e.g., the sensor systems manufactured and distributed by PreSens $\mathrm{GmbH}$, Regensburg, Germany), or a phase-shift detection scheme (e.g., the oxygen optode manufactured and distributed by Aanderaa, Bergen, Norway. Note that the Aanderaa system is based on an oxygen-sensitive foil manufactured by PreSens; Aanderaa supplied the electronics and packaging to make it into an oceanographic instrument).

The relatively slow response of these optical probes (see e.g., Glazer et al., 2004) results from the presence of a gas-permeable membrane placed over the sensing foil containing the immobilized chromophore (usually a ruthenium complex). This membrane is added to make the sensor more rugged, to avoid interferences from fluorescent materials in the water, and to protect the sensor from direct sunlight. As yet, there has been only limited use of such sensors in the oceanographic community. A number of groups are presently evaluating the Aanderaa sensors for various applications: drifters, mooring, profiling floats and first indications show promise. Potential science that can be done with such a sensor attached to a profiling float is indicated in Joos et al. (2003).

As with the Clark-type sensors, effective temperature compensation is an essential part of the sensor calibration and a cornerstone of accurate measurements in an environment where the temperature changes. The sensors are also pressure sensitive, the sensitivity to oxygen being slightly lessened at increased pressures.

Another promising new technology for oxygen measurements is membrane inlet mass spectrometry (see e.g., http:// www.hpl.umces.edu/dga/), which has been engineered to perform underwater (see e.g., http://cot.marine.usf.edu/hems/underwater/). Using this approach, in situ oxygen, as well as argon and nitrogen, may be measured. Quantitative assessment of this suite of gases can provide useful benchmarks for data interpretation.

A final approach to measuring the oxygen partial pressure in water in a moored system involves using a so-called gas tension device (Pro-Oceanus Systems, Halifax, Canada). This determines total gas pressure in water by direct measurement of the pressure on the gaseous side of a gas-permeable membrane that is in contact with the water. Using such a device in concert with a second similar device that incorporates a chemical absorbent for oxygen, thus removing oxygen more quickly than it diffuses through the gaspermeable membrane, allows an estimate of the oxygen partial pressure by difference. As yet, there is limited experience with this dual system; however, the original gas tension device is capable of excellent long-term precision and is well-suited for use on a mooring (see e.g., Emerson et al., 2002).

In conclusion, there is no single perfect approach to measuring oxygen concentrations in seawater at this time. The newest incarnation of the Clark-type sensor (the Sea-Bird SBE 43) seems to be robust and is designed for profiling applications. Its long-term drift (over a period of a year), however, is expected to be significant. The second-generation pulsed oxygen sensors (currently only available as prototypes) include modifications aimed at extending battery life, increasing data storage capacity by data compression algorithms, improving membrane and solution stability, and new anti-fouling schemes. As a result, their operational period has been extended up to six months. The Aanderaa optode has been tested to have a long-term stability (more than 6 months), although its response time is slow (up to a few minutes). It is being incorporated into a number of platforms (moorings, profiling floats, drifters) at this time, and the results of this more widespread use should become known in the coming year or so. As this experience is gained, the efficacy of the various prophylactics against biofouling, an essential part of long-term stability, will become clearer.

\section{Nutrient Sensors}

Although a wide variety of elements are essential to life in the oceans, only a relatively small number of essential elements are classified as nutrients. Elements such as nitrogen, phosphorus and silicon are termed nutrients based on their distinctive vertical profiles in the upper ocean. The profiles of nutrient elements exhibit an extraordinary dynamic range. Nutrients characteristically have high concentrations in the deep ocean, while concentrations near the surface are often below detection limits even for state-of-the-art instrumentation. The gradient of nutrient concentrations in the transition zone, between high and low concentrations, generally encompasses the euphotic zone and can be very dynamic in response to both physical and biological processes. Thus, in situ nutrient measurements are exceptionally challenging.

Essentially all labile inorganic and organic forms of nitrogen, phosphorus, and silicon can be considered as priority analytes. Important bioavailable forms of nitrogen include ammonia, nitrite, nitrate and urea. Impor- 
tant forms of phosphorus include both orthophosphate and organic species, while dissolved silicon in seawater is considered to be present strictly as monomeric forms of silicic acid. All of the nutrient sensors described in Table 2 are based on either conventional colorimetric procedures or direct measurements via UV spectroscopy. Potentiometric measurements of nitrate and ammonia (YSI Inc.) are suitable only for freshwater environments. The spectrophotometric sensors shown in Table 2 have a wide range of response times, physical dimensions, power requirements and measurement capabilities.

The UV sensors for nitrate absorbance measurements (MBARI-ISUS and SUV-6) at the top of Table 2 are notable for their fast response times (seconds). These sensors may be especially suitable for profiling operations. The sensitivity of direct (reagentless) nitrate measurements is likely somewhat poorer than that of some of the Table 2 colorimetric sensors. The limit of detection for one ISUS observation is on the order of $1.5 \mu \mathrm{M}( \pm 3$ $\mathrm{SD}$ ), while 30 seconds of signal averaging can reduce the detection limit to $0.2 \mu \mathrm{M}$ (Johnson and Coletti, 2002). The resolution limit of the SUV-6 is also given as $0.2 \mu \mathrm{M}$ (Finch et al., 1998; Prien and Hydes, 2003).

The NPA and DPA instruments of SYSTEA are capable of measuring four nutrients per instrument (Table 2). The maxi- mum deployment depths of the two sensors are $10 \mathrm{~m}$ and $4500 \mathrm{~m}$. The detection limits for ammonia, phosphate, nitrite and nitrite plus nitrate are given as $50 \mathrm{nM}, 10 \mathrm{nM}, 11$ $\mathrm{nM}$ and $16 \mathrm{nM}$ for the NPA system, and $100 \mathrm{nM}, 10 \mathrm{nM}, 13 \mathrm{nM}$ and $32 \mathrm{nM}$ for the DPA system. No documentation for the stated sensitivities is currently available. It is stated that both of these four-channel systems are capable of measuring silicate in place of one of the other nutrients. Measurements of different nutrients are sequential. The endurance of these instruments in moored operation is stated in different forms: (a) up to one month depending on measurement intervals, (b) 350 total measurements, and (c) four to

\section{TABLE 2}

Current status of nutrient sensors. Development stages and deployment designations as in Table 1.

Sampling time is sensor's processing time per sample in seconds (s), minutes (min), or hours

\begin{tabular}{|c|c|c|c|c|c|c|}
\hline Sensor & $\begin{array}{l}\text { Analytes } \\
\text { measured }\end{array}$ & $\begin{array}{l}\text { Development } \\
\text { stage }\end{array}$ & $\begin{array}{l}\text { Power } \\
\text { (Watts) }\end{array}$ & $\begin{array}{l}\text { Sampling } \\
\text { time }\end{array}$ & $\begin{array}{l}\text { Deployment } \\
\text { capability }\end{array}$ & Source/Contact \\
\hline MBARI-ISUS & nitrate & I & 12 & $\mathrm{~s}$ & $M, A, P, T, R, B$ & $\begin{array}{l}\text { Satlantic/ WETSAT } \\
\text { www.satlantic.com www.wetsat.com }\end{array}$ \\
\hline SUV-6 & nitrate & V & 4 & S & $P$ & $\begin{array}{l}\text { Ralf Prien OED-SOC } \\
\text { Ralf.prien@soc.soton.ac.uk } \\
\text { www.valport.co.uk }\end{array}$ \\
\hline NPA & $\begin{array}{l}\text { nitrite } \\
\text { nitrate/nitrite } \\
\text { orthophosphate } \\
\text { ammonia }\end{array}$ & I & 10 & $\min$ & M & SYSTEA, www.systea.it \\
\hline DPA & $\begin{array}{l}\text { nitrite } \\
\text { nitrate/nitrite } \\
\text { orthophosphate } \\
\text { ammonia }\end{array}$ & I & 7 & $\min$ & $\mathrm{M}, \mathrm{A}, \mathrm{P}, \mathrm{T}, \mathrm{R}$ & SYSTEA, www.systea.it \\
\hline TPA & $\begin{array}{l}\text { Tot. nitrogen } \\
\text { Tot. phosphorous }\end{array}$ & 1 & $10-20$ & $\sim 0.5$ hour & M & SYSTEA, www.systea.it \\
\hline NAS-3X & $\begin{array}{l}\text { nitrate } \\
\text { silicate } \\
\text { phosphate } \\
\text { ammonium }\end{array}$ & 1 & $\sim 3.4$ & $\min$ & $\mathrm{M}, \mathrm{P}$ & EnviroTech LLC, www.n-virotech.com \\
\hline EcoLAB & $\begin{array}{l}\text { nitrate } \\
\text { silicate } \\
\text { phosphate } \\
\text { ammonium }\end{array}$ & 1 & 3.1 & $\min$ & $\mathrm{M}, \mathrm{P}$ & EnviroTech LLC, www.n-virotech.com \\
\hline SubChemPak & $\begin{array}{l}\text { nitrate } \\
\text { nitrite } \\
\mathrm{Fe}^{\prime \prime} / \mathrm{Fe}^{|l|} \\
\text { phosphate }\end{array}$ & I & $\begin{array}{l}50- \\
150\end{array}$ & $\begin{array}{l}\mathrm{s} \\
\mathrm{s} \\
\mathrm{s} \\
\mathrm{min}\end{array}$ & M,A,P,T,R & $\begin{array}{l}\text { SubChem Systems, Inc. } \\
\text { www.subchem.com }\end{array}$ \\
\hline $\begin{array}{l}\text { DigiSCAN } \\
\text { YSI } 9600\end{array}$ & $\begin{array}{l}\text { nitrate } \\
\text { phosphate }\end{array}$ & II & & $\min$ & M,A,P,T,R & $\begin{array}{l}\text { YSI Inc. } \\
\text { www.ysi.com }\end{array}$ \\
\hline SEAS-II & $\begin{array}{l}\text { nitrate } \\
\text { nitrite } \\
\mathrm{Fe}^{\prime \prime} / \mathrm{Fe}^{\mathrm{III}} \\
\text { ammonia } \\
\mathrm{Cu}\end{array}$ & $\begin{array}{l}\mathrm{V} \\
\mathrm{V} \\
\mathrm{VI} \\
\mathrm{VI} \\
\mathrm{VI}\end{array}$ & 15 & $\begin{array}{l}\mathrm{S} \\
\mathrm{s} \\
\mathrm{S} \\
\min \\
\mathrm{min}\end{array}$ & $M, A, P, T, R$ & R. Byrne, USF-COT*, byrne@.marine.usf.edu \\
\hline
\end{tabular}

*University of South Florida - Center for Ocean Technology ${ }^{* \star}$ Ocean Engineering Division - Southampton Oceanography Center 
ten weeks due to reagent expiration. In the absence of special reagent preservation procedures, the less than ten-week limitation imposed by reagent degradation would be common to all wet chemical colorimetric procedures. The TPA system of SYSTEA is capable of total nitrogen and total phosphorous in place of ammonia and nitrite. The detection limits for total $\mathrm{N}$ and $\mathrm{P}$ is given as $3 \mathrm{ppb}$ and $2 \mathrm{ppb}$. The TPA system is generally similar to the NPA and TPA systems, and it is stated that approximately one hour is required for a full cycle of four measurements.

The NAS-3X and EcoLAB systems of Envirotech LLC provide nutrient measurements with stated detection limits equal to $50 \mathrm{nM}$ for nitrate and ammonium and 60 $\mathrm{nM}$ for phosphate and silicate. The EcoLab system is a four-channel version of the NAS$3 \mathrm{X}$ in which four nutrients are measured simultaneously. The endurance for nitrate, ammonium, phosphate and silicate measurements are six months, four months, two months and two months, respectively. The standard depth capability for both instruments is $100 \mathrm{~m}$, with options for $250 \mathrm{~m}$ and greater. These sensors are stated to be extremely resistant to biofouling. However, the characteristics of these sensors are not well documented in scientific publications.

The SubChemPak analyzer is a three wavelength, four-channel system comprised of the SubChem Systems, Inc. reagent delivery module and the ChemStar four-channel absorption detector of WET Labs, Inc. Measurements of nitrite, nitrate, phosphate and $\mathrm{Fe}{ }^{\mathrm{III}} / \mathrm{Fe}^{\mathrm{II}}$ can be obtained to depths of $200 \mathrm{~m}$. Previous descriptions of this sensor (Hanson and Moore, 2001) have emphasized its use for measurements of spatial distributions (profiling and towed deployments). The system's relatively high power consumption would not be problematic in these cases. The $15 \mathrm{~cm}$ pathlength of the SubChemPac system is unique among commercially available sensors. This relatively long pathlength should translate to detection limits on the order of ten nanomolar.

The MBARI sensor, originally known as the DigiSCAN, is scheduled for commercial production as the YSI 9600 Nitrate Analyzer. Some aspects of the operation of this system were described by Weeks and Johnson (1996). The resolution of this sensor for nitrate measurements is stated as approximately $0.16 \mu \mathrm{M}$. The system can also be adapted for phosphate measurements. The instrument has been deployed in various environments for periods between one and three months with samples taken once per hour.

The SEAS-II sensor of USF-COT is a single channel system that can be used for both absorbance and fluorescence measurements. Pathlengths on the order of one to two meters promote high sensitivity and high resolution. Iron and nitrite, for example, can be measured with detection limits on the order of $2 \mathrm{nM}$. The sensor's Ocean Optics diode array detector allows measurements at user-defined wavelengths. Measurements are obtained at a frequency up to approximately $1 \mathrm{~Hz}$. Both sampling frequency and the timing of measurements are user defined. Using only the sensor's internal batteries, electrical endurance is 190 watt-hours. The sensor's depth range is 500 meters. SEAS-I characteristics are described by Steimle et al. (2002) and Callahan et al. (2004).

A number of novel sensors have not been included in Table 2. The osmotically pumped nitrate analyzer (OsmoAnalyzer) described by Jannasch et al. (1994) utilizes conventional colorimetric chemistries and has a detection limit of $100 \mathrm{nM}$, with a measurement time somewhat less than one hour. This instrument was successfully operated in a saltwater aquarium for approximately one month and performance was assessed during several field studies (e.g., Chapin et al., 2002; McGillicuddy et al., 1998). The nitrite/nitrate analyzer of Daniel et al. (1995 a, b), which is also based on conventional colorimetric analysis, has a 40/ hr measurement frequency and a nitrate detection limit of $0.45 \mu \mathrm{M}$. The analyzer was connected to an attending vessel via a $300 \mathrm{~m}$ power cable, which also linked the sensor's electronics with the shipboard central processing electronics. Floch et al. (1998) used an identical system for silicate measurements with a detection limit of $0.3 \mu \mathrm{M}$. In addition, Masserini and Fanning (2000) have described a three-channel shipboard analyzer for fluorimetric analysis of nitrite, nitrate and ammonia. The system is being prepared for in situ deployment and has reported detection limits of $4.6 \mathrm{nM}$ (nitrite), $6.9 \mathrm{nM}$ (nitrate) and $1 \mathrm{nM}$ (ammonia).

The sensors depicted in Table 2 have a wide range of measurement objectives and, accordingly, a wide range of capabilities. Since direct UV observations of nitrate (MBARIISUS and SUV-6) are exceptionally fast, these sensors are ideal for obtaining very rapid chemical profiles. Both of these sensors are also suitable for long-term measurements, but the sensitivity and specificity of direct UV detection is expected to be somewhat poorer than is the case for measurements obtained using wet chemical procedures. The SubChemPak and SEAS sensors are oriented toward profiling and towed operations, but are also capable of long-term measurements. The long pathlength of these systems allows not only increased sensitivity, but also an enhanced rate of sampling because relatively high absorbances can be obtained before colorimetric reactions have gone to completion. As evidenced by relatively long sampling times, most of the remaining sensors in Table 2 are oriented toward moored operations, but can in principle also be used for observations of spatial distributions. The sensitivities listed for the various sensors in Table 2 are not altogether consistent. For the colorimetric sensors in the table, the best guide to sensitivity will be the molar absorbances of sensed analytes and spectrometric pathlength (Byrne et al., 1999). In general, there is an extreme dearth of peer-reviewed discussion of instrumental characteristics and operation in the field. Some instruments are marketed with essentially no peer-reviewed documentation of instrumental capabilities.

\section{Carbon System Sensors}

Primary $\mathrm{CO}_{2}$ system variables include $\mathrm{CO}_{2}$ fugacity $\left(\mathrm{f}_{\mathrm{CO} 2}\right)$ or partial pressure $\left(\mathrm{pCO}_{2}\right), \mathrm{pH}\left(-\log \left[\mathrm{H}^{+}\right]\right)$, total dissolved inorganic carbon $\left(\mathrm{C}_{\mathrm{T}}\right)$, and total alkalinity $\left(\mathrm{A}_{\mathrm{T}}\right)$. Three of these primary variables $\left(\mathrm{f}_{\mathrm{CO} 2}\right.$, $\mathrm{pH}, \mathrm{C}_{\mathrm{T}}$ ) are directly linked via equilibrium thermodynamics, while the relationship between $A_{T}$ and the remaining primary variables requires an assessment of the alkalin- 
Current status of in situ $\mathrm{CO}_{2}$ system sensors. Development stages and deployment designations as in Table 1. Sampling time is sensor's processing time per sample in seconds (s), minutes (min), or hours

\begin{tabular}{|c|c|c|c|c|c|c|}
\hline Sensor & $\begin{array}{l}\text { Analytes } \\
\text { measured }\end{array}$ & $\begin{array}{l}\text { Development } \\
\text { stage }\end{array}$ & $\begin{array}{l}\text { Power } \\
\text { (Watts) }\end{array}$ & $\begin{array}{l}\text { Sampling } \\
\text { time }\end{array}$ & $\begin{array}{l}\text { Deployment } \\
\text { capability }\end{array}$ & Source/Contact \\
\hline $\begin{array}{l}\text { SAMI- }-\mathrm{CO}_{2} \\
\text { SAMI-1500 }\end{array}$ & $\mathrm{fCO}_{2}$ & 1 & 2.4 & $\min$ & MM,P & $\begin{array}{l}\text { Sunburst Sensors } \\
\text { www.sunburstsensors.com }\end{array}$ \\
\hline CARIOCA & $\mathrm{fCO}_{2}$ & II & & $\min$ & M & $\begin{array}{l}\text { http://www.lodyc.jussieu.fr/ } \\
\text { carioca/home.html }\end{array}$ \\
\hline $\begin{array}{l}\text { MBARI- } \\
\triangle \mathrm{pCO}_{2}\end{array}$ & $\begin{array}{l}\triangle p \mathrm{CO}_{2} \\
\text { atm/seasurface }\end{array}$ & II & $8-12$ & $\min$ & M & $\begin{array}{l}\text { LI-COR Inc. } \\
\text { http://www.licor.com/env/ }\end{array}$ \\
\hline $\begin{array}{l}\text { Fiber-optic } \\
\mathrm{CO}_{2} \text { sensor }\end{array}$ & $p \mathrm{CO}_{2}$ & V & & & M & $\begin{array}{l}\text { D. Walt, MTLOC-DC*-Tufts } \\
\text { dwalt@emerald.tufts.edu }\end{array}$ \\
\hline SAMI-pH & $\mathrm{pH}$ & V & $\sim 2.4$ & $\min$ & M & $\begin{array}{l}\text { M. Degrandpre, UM } \\
\text { mdegrand@selway.umt.edu }\end{array}$ \\
\hline SEAS-II & $\mathrm{pH}$ & V & 15 & s & $M, P, A, T, R$ & $\begin{array}{l}\text { R. Byrne, USF-COT }{ }^{* *} \\
\text { byrne@marine.usf.edu }\end{array}$ \\
\hline AMpS & $\mathrm{pH}$ & VI & $\sim 10$ & s & $M, P, A, T, R$ & $\begin{array}{l}\text { R. Bellerby, BCCR-GI-UB }{ }^{\dagger} \\
\text { richard.bellerby@gfi.uib.no }\end{array}$ \\
\hline $\begin{array}{l}\text { Deep-sea pH } \\
\text { probe }\end{array}$ & $\mathrm{pH}$ & $\mathrm{VI}$ & & s & $M, P, R$ & $\begin{array}{l}\text { N. Le Bris, IFREMER } \\
\text { nadiene.le.bris@ifremer.fr }\end{array}$ \\
\hline RATS & $\mathrm{C}_{\mathrm{T}}$ & V & & $\min$ & M & F. Sayles, WHOI, fsayles@whoi.edu \\
\hline
\end{tabular}

"Max Tishler Laboratory for Organic Chemistry, Department of Chemistry, Tufts University " University of South Florida - Center for Ocean Technology

tBjerknes Center for Climate Research, Geophysical Institute, University of Bergen

ity contributions of minor protolytes including borate, phosphate and silicate. Requirements for accuracy and precision of $\mathrm{C}_{\mathrm{T}}$ and $A_{T}$ measurements are generally stringent because of the limited dynamic range of these variables in seawater. In best practice, shipboard measurements of these two variables, via coulometry and acid-base titrimetry, provide precisions on the order of $1-2 \mu \mathrm{M}$ and $2-4 \mu \mathrm{M}$ respectively. The achievable precision for spectrophotometric $\mathrm{pH}$ measurements, on the order of $0.0004 \mathrm{pH}$ units, allows ocean $\mathrm{pH}$ to be measured with a high resolution. Similar results can be achieved for measurements of $\mathrm{f}_{\mathrm{CO} 2}$.

Measurements of $\mathrm{f}_{\mathrm{CO} 2}$ typically involve either infra-red measurements of $\mathrm{CO}_{2}$ in a gas phase that has been equilibrated with the seawater (either by direct contact, or through a membrane that is permeable to unionized $\mathrm{CO}_{2}$ ), or measurements of $\mathrm{pH}$ in a solution phase of known alkalinity that has been equilibrated with the seawater (again through a membrane that is permeable to unionized $\mathrm{CO}_{2}$ ). Direct measurements of seawater $\mathrm{pH}$, as well as $\mathrm{pH}$ measurements in equilibrated solutions for the purposes of $\mathrm{f}_{\mathrm{CO} 2}$ measurements, generally involve spectrophotometric observations of indicator absorbance ra- tios. Such measurements, in good practice, have very stable calibrations that do not require additional calibration in the field. These calibrations depend predominantly on the properties of the indicator dye itself, and to a much smaller extent on the properties of the spectrophotometer that is being used (Robert-Baldo et al., 1985; DeGrandpre and Baehr, 1999). The coulometric and titrimetric procedures used on shipboard for $\mathrm{C}_{\mathrm{T}}$ and $\mathrm{A}_{\mathrm{T}}$ measurements are not readily amenable to in situ analysis. As such, progress on sensors for these variables has generally been slower than for measurements of the remaining primary variables. The sensors listed in Table 3 for measurements of $\mathrm{C}_{\mathrm{T}}$ and $\mathrm{A}_{\mathrm{T}}$ involve procedures that are distinct from those used in shipboard analyses.

The performance characteristics of the SAMI-CO 2 sensor are especially well documented (DeGrandpre, 1993; Degrandpre et al., 1995, 2000; Degrandpre and Baehr, 1999), and the sensor has been routinely used for scientific investigations (DeGrandpre et al., 2002; Baehr and Degrandpre, 2004). Observations of dissolved indicator absorbance ratios provide $\mathrm{f}_{\mathrm{CO} 2}$ relative precisions on the order of 0.3 to $1 \%$. The system is reported to be capable of year-long deployments, and has performed well in low temperature environments over a period of five months. The operational principles of the CARIOCA $\mathrm{f}_{\mathrm{CO} 2}$ sensor (Lefevre et al., 1993) are similar to those of the SAMI-CO ${ }_{2}$ sensor, and the performance characteristics of the two instruments appear to be generally similar. Although the time constant for sensor equilibration appears to be somewhat longer for the CARIOCA system (20 minutes) than for the SAMI system (5 minutes), hourly sampling should be adequate for oceanic observations on moorings. CARIOCA measurements have been compared with shipboard $\mathrm{f}_{\mathrm{CO} 2}$ measurements in the Sargasso Sea (Bates et al., 2000), and the instrument has been used on drift buoys in the Greenland Sea for a period of six months (Hood and Merlivat, 1999).

The $\mathrm{pCO}_{2}$ measurement system of Friederich et al. (1995) is designed for precise observations of differences in $\mathrm{CO}_{2}$ partial pressure at the air/sea interface $\left(\Delta \mathrm{pCO}_{2}\right)$. The sensor is based on commercially available instrumentation for non-dispersive infrared spectrophotometry. Deployments in excess of two months evidenced excellent instrumental stability. This instrumentation is routinely used for scientific observations (Chavez et al., 1999). 
The $\mathrm{pCO}_{2}$ sensor of Tabacco et al. (1999), presented in Table 3, is a fluorescence-based fiber optic system in a relatively early stage of development. Although the sensor exhibited long-term drift in sea trials, and the overall performance characteristics of the system are not well characterized relative to the SAMI and CARIOCA systems, the methodology appears to be promising and is currently being tested by YSI.

SAMI-pH sensors utilize indicator absorbance ratios to achieve a measurement precision better than $+/-0.005 \mathrm{pH}$ units (Martz et al., 2003). SAMI-pH measurements agree with laboratory spectrophotometric $\mathrm{pH}$ measurements within approximately 0.003 units. The instrument has a response time on the order of six minutes, and appears to be well suited to long-term moored operations. Like the SAMI-pH sensor, SEAS $\mathrm{pH}$ measurements are based on absorbance measurements at three wavelengths. Although SEAS-pH sensor development has emphasized a rapid response time $(-2 s)$ for profiling operations, the instrument has also been used for moored measurements in the North Pacific over a period of approximately three weeks. The spectrophotometric response of the system, which utilizes an Ocean Optics CCD array spectrometer, is essentially identical to that of laboratory instruments (e.g. HP 8453), and short-term precision is approximately 0.001 $\mathrm{pH}$ units.

The AMpS shipboard spectrophotometric system (Bellerby et al., 2002) achieves an on-line precision better than $0.001 \mathrm{pH}$ units with a measurement frequency of 20 samples per hour. The system is suitable for moored measurements in the surface ocean, and a miniaturized sensor is being prepared for deep-sea operations. The shipboard spectrophotometric system of Tapp et al. (2000) has a precision similar to that of the AMpS system, indicating that $\mathrm{pH}$ precisions on the order of 0.001 and better can be routinely achieved using compact CCD array spectrometers. The system of Tapp et al. (2000) is apparently not being modified for autonomous deployments.

Due to stringent requirements for precision and accuracy, potentiometric $\mathrm{pH}$ sensors are not generally suitable for autonomous measurements in the surface ocean. For the purpose of $\mathrm{CO}_{2}$ system characterizations in surface waters, measurement resolutions on the order of 0.01 and accuracies between 0.1 and 0.2 are unsatisfactory. Nevertheless, potentiometric $\mathrm{pH}$ measurements can be quite useful in some circumstances. The very large $\mathrm{pH}$ range and sharp $\mathrm{pH}$ gradients in hydrothermal systems somewhat reduces the significance of accuracy and precision and heightens the importance of rapid response times. Le Bris et al. (2001) demonstrate the utility of potentiometric $\mathrm{pH}$ measurements subsequent to careful consideration of the influences of pressure, and especially temperature, on electrode calibrations (slopes and intercepts). A variety of potentiometric $\mathrm{pH}$ sensors, including those of In-Situ Inc. (www.insitu.com), Sea-Bird (www.seabird.com), and YSI (environmental. YSI.com), may also prove useful for examination of $\mathrm{pH}$ gradients in benthic systems that are approximately isothermal.

The WHOI/Sayles RATS sensor is currently the only operational in situ system for total $\mathrm{CO}_{2}$ measurements. Measurements are obtained conductimetrically following exchange of $\mathrm{CO}_{2}$ between acidified seawater and the interior of a $\mathrm{CO}_{2}$ permeable tube that contains dilute $\mathrm{NaOH}$. Six-week tests over a temperature range between $8^{\circ}$ and $24^{\circ}$ $\mathrm{C}$, as well as in situ tests over a period of two weeks, produced measurement precisions equal to $\pm 2 \mu \mathrm{M}$ in each case (Sayles, personal communication). System endurance based on either power consumption or reagent limitation is -700 analyses. This sensor system incorporates spectrophotometric $\mathrm{pH}$ measurements to provide a comprehensive description of the marine $\mathrm{CO}_{2}$ system.

In situ membrane introduction mass spectrophometers (Short et al., 2001; Wenner et al., 2004) are currently being adapted for measurements of total $\mathrm{CO}_{2}$. This new capability requires only the addition of in-line acidification to current technology already available.

A shipboard system for measurements of $\mathrm{pH}, \mathrm{f}_{\mathrm{CO} 2}$ and $\mathrm{C}_{\mathrm{T}}$ (Byrne et al., 2002) is currently undergoing sea trials. In situ measurements are planned for 2004 - 2005. A system for potentiometric $\mathrm{C}_{\mathrm{T}}$ has been described by Choi et al. (2002). While this sensor may be useful in some applications, the system's 30 $\mu \mathrm{M}$ measurement imprecision presently precludes its use in $\mathrm{CO}_{2}$ system studies.

There are presently no sensor systems being tested for autonomous in situ alkalinity analyses. It has been shown, however, that $\mathrm{A}_{\mathrm{T}}$ measurements can be obtained using the same system that is currently being readied for in situ measurements of $\mathrm{pH}, \mathrm{f}_{\mathrm{CO} 2}$ and $\mathrm{C}_{\mathrm{T}}$.

\section{Biological Sensors}

Conventional sampling technologies (e.g., water bottles, nets, pumps) limit the ability of biological oceanographers to assess the abundance and distribution of organisms over a broad range of temporal and spatial scales. Observations need to be made at space and time scales relevant to organisms' behavior and physiology and life history rate measurements. Optics and acoustics are the primary technologies currently being used to detect and identify organisms in the water column, however, neither can quantify all the critical variables alone and both have strengths and limitations. For example, most optical sensors resolve targets on small spatial scales ( $\mu \mathrm{m}$ to $\mathrm{m}$ ), while acoustics is the only method available that can detect zooplankton and fish over much larger spatial scales ( $\mathrm{mm}$ to $\mathrm{km}$ ) and provide a visualization of biophysical interactions in aquatic systems. Both methods share a common background in wave propagation theory, which uses properties of absorption and scattering. Both technologies also have experienced major advances in hardware and software development, particularly in signal and imaging processing, and in model development in the last two decades. The Grand Challenge for these technologies is still remote species identification. Optical scattering and absorption sensors now routinely provide information on particle size and density, phytoplankton phylogenetic groups (i.e., diatoms, prymnesiophytes), and estimates of photosynthesis (reviewed in Dickey and Chang, 2001), but only imaging and microscopy by humans has yielded species identification. Some optical sensors are being deployed on moorings, drifters, and gliders but only a few bioacoustic sen- 
sors have been deployed on moorings or Autonomous Underwater Vehicles (AUVs) for short durations (days-months). Numerous optical imaging systems to assess phytoplankton and zooplankton (see reviews in Jaffe et al., 2001; Wiebe and Benfield, 2003) have been developed in the last few decades, but few are capable of long-term deployment as part of observatories. Recent advances focus on the use of sensing systems which integrate a suite of 'smart' sensors (e.g., optics, acoustics, environmental variables). It is envisioned that these systems will be capable of automated internal calibrations in situ, and that they will be able to detect changing gradients and then make decisions about altering sampling intervals or send an alert back to shore for further instructions.

Some of the challenges for developing optical sensors for mobile platforms are generic, while others are more or less stringent depending on the platform constraints and intended mission duration (Rudnick and Perry, 2003). For example and in contrast to floats and gliders, powered AUVs can accommodate larger payloads and sensors with higher power demands, such as multiwavelength spectrometers, imaging systems, and flow cytometers. Only radiometric sensors that are sufficiently small and power conservative have been incorporated into floats and gliders (i.e., downwelling irradiance, beam c, backscattering, and fluorescence sensors). Other engineering challenges become important only for longer deployment. For missions of short duration (i.e., days) issues of biofouling and sensor drift are not as great a concern as they are for missions lasting from months to years.

\section{Optical sensors}

Radiometric measurements in the near UV and visible wavebands are widely used as proxy measurements for important biogeochemical variables in the ocean. Phytoplankton absorb visible radiation predominately in the blue, blue-green, and red portions of the visible spectrum as a function of pigment composition and fluorescence or re-emit a small fraction of absorbed light at $683 \mathrm{~nm}$. Their scattering spectrum is dependent on size (ranging from $\sim 0.7 \mu \mathrm{m}$ to several hundred microns), refractive index, and absorption spectrum. Non-algal organic particles, such as bacteria and detritus, are relatively weak scatterers and absorbers, with absorption maxima in the UV. Chromophoric dissolved organic matter (CDOM) strongly absorbs in the UV, its peaks associated with humic and fulvic acids, mycosporin-like amino acids (MAAs), nucleic acids, and specific amino acids. Suspended minerals are highly efficient scatterers, although strong absorption features have been observed in iron-rich minerals. The optical sensors used to measure these proxies include active radiometric systems with integrated light sources and passive radiometers deployed in- or above-water. Protocols for many sensors are published as JGOFS procedures and NASA SIMBIOS documents. Because several variables may contribute to the optical signal at any single wavelength, it is often necessary to use a combination of measurements to decrease uncertainty in proxy resolution. Variability in the fundamental relationship between the optical measurement and the concentration of the proxy also argue for a combination of measurements to reduce uncertainty in the conversion factor. A rich literature exists for extraction of proxy information from optical sensors.

Active optical sensors use lamps or LEDs as the light source and measure inherent optical properties (IOPs, i.e., properties not affected by natural illumination conditions) such as absorption (a), scattering (b), and attenuation coefficients $(c=a+b)$. Passive radiometers depend upon natural illumination conditions and measure apparent optical properties (AOPs) such as downwelling irradiance $\left(\mathrm{E}_{\mathrm{d}}\right)$, upwelling radiance $\left(\mathrm{L}_{\mathrm{u}}\right)$, diffuse attenuation coefficient $\left(\mathrm{K}_{\mathrm{d}}\right)$, and reflectance. IOPs and AOPs are related via the radiative transfer equation, and IOPs can be estimated from AOPs through solution or inversion of the radiative transfer equation (cf. Gordon et al., 1975). Because IOP sensors have internal light sources, power consumption rates are higher than for passive sensors. However, they can operate at night and below the photic zone, making it possible to detect phenomena such as diel changes in particle concentration, sinking phytoplankton aggregations, and detached nephaloid layers. AOP instruments depend only on sunlight and therefore consume less power. However, they cannot operate at night or below the photic zone (typically 10 to $150 \mathrm{~m}$, depending on the concentration of optically active material in the water).

The WET Labs ac-9 (so-named because it measures absorption and attenuation at nine wavelengths, and allows total scattering to be derived) was introduced in the last decade and has been widely deployed from ships using profiling and towed systems and on moorings for weeks to months (Table 4). These meters are flow-through systems with path length options of $25 \mathrm{~cm}$ for open ocean waters and $10 \mathrm{~cm}$ for more turbid waters. Recent modifications have increased the number of wavelengths measured and improved electronic stability. Although not commercially available, Kirkpatrick et al. (2003) developed a liquid-capillary waveguide to measure CDOM; this system has also been used for total particulate absorption measurements on AUVs and gliders. Size and power consumption limit current autonomous application of absorption meters to moorings and short-term deployments on autonomous platforms. The use of copper tubing on the inlets of ac-9s has reduced biofouling on mooring applications (Chavez et al., 2000), but in highly productive regions biofouling remains a serious problem. Drift in calibration during long-term deployments remains problematic, but could be addressed by metered injections of a calibration dye, similar to systems being developed for nutrient standards in conventional colorimetric nutrient analyzers. Small transmissometers such as the C-Rover, provide light-weight options for mobile platforms, but are less rugged than traditional transmissometers, a potential logistical drawback for the rigors of ship-launched deployments of moorings in hostile environments. Sequoia Scientific's LISST (Laser In-Situ Scattering and Transmissometry) measures small-angle, nearforward scattering with a laser diffraction technology. The LISST provides a robust 
measurement of particle size distribution; a choice of size ranges and additional parameters are available from several different models. The HOBI Labs C-Beta offers an alternative measurement for the beam attenuation coefficient, using a folded-path geometry for 30 and $90 \mathrm{~cm}$ path lengths. A choice of backscattering sensors exist that use flush-mounted optical windows to measure multiple angles of backscatter and offer a selection of wavelengths. Pulse modulation of the signal minimizes con- tamination by ambient light, allowing measurement in full sunlight. The size and power consumption vary, from the larger HOBI Labs' HydroScat-6 (six wavelengths) to the smaller WET Labs' ECO VSF series. Turbidity meters, such as offered by

\section{TABLE 4}

Current status of optical sensors for commercially available examples. Development stages, power [based on available information; watts (W), amps(A)] and deployment designations as in Table 1. Sampling time is sensor's processing time per sample in seconds (s), minutes (min), or hours

\begin{tabular}{|c|c|c|c|c|c|}
\hline Sensor & $\begin{array}{l}\text { Development } \\
\text { stage }\end{array}$ & Power & $\begin{array}{l}\text { Sampling } \\
\text { time }\end{array}$ & $\begin{array}{l}\text { Deployment } \\
\text { capability }\end{array}$ & $\begin{array}{l}\text { Source/ } \\
\text { contact }\end{array}$ \\
\hline $\begin{array}{l}\text { ac-9 } \\
\text { absorption \& } \\
\text { attenuation meter }\end{array}$ & l & 9 W @12 VDC & $\mathrm{s}$ & $\mathrm{M}, \mathrm{P}, \mathrm{T}, \mathrm{A}$ & Wet Labs, www.wetlabs.com \\
\hline $\begin{array}{l}\text { C-Rover } \\
\text { transmissometer }\end{array}$ & I & $400 \mathrm{~mW}$ & s & $\mathrm{D}, \mathrm{A}$ & Wet Labs, www.wetlabs.com \\
\hline $\begin{array}{l}\text { C-Beta } \\
\text { backscattering } \\
\text { \& attenuation }\end{array}$ & I & 70 mA @ 15 VDC & s & $\mathrm{M}, \mathrm{T}$ & HOBI Labs, www.hobilabs.com \\
\hline $\begin{array}{l}\text { CYCLOPS-7 } \\
\text { chlorophyll } \\
\text { fluorometer }\end{array}$ & I & $<300 \mathrm{~mW}$ & s & M,P,T,A,S & Turner Designs, www.turnerdesigns.com \\
\hline $\begin{array}{l}\text { ECO Pucks }{ }^{\mathrm{TM}} \\
\text { fluorometer or } \\
\text { scattering meter }\end{array}$ & 1 & $70 \mathrm{~mA} 7-15$ at VDC & s & all & Wet Labs, www.wetlabs.com \\
\hline $\begin{array}{l}\text { UV AQUAtracka } \\
\text { CDOM and } \\
\text { hydrocarbon } \\
\text { fluorometer }\end{array}$ & I & $495 \mathrm{~mA}$ at $12 \mathrm{~V}$ d.c. & s & $\mathrm{M}, \mathrm{T}, \mathrm{S}$ & Chelsea Technologies, www.chelsea.co.uk \\
\hline $\begin{array}{l}\text { LISST } \\
\text { Laser In Situ } \\
\text { Scattering and } \\
\text { Transmissometry }\end{array}$ & I & 160 mA @ 9 V max & s & $\mathrm{M}, \mathrm{A}, \mathrm{T}$ & Sequoia Scientific, Inc., www.sequoiasci.com \\
\hline $\begin{array}{l}\text { HydroScat-6 } \\
\text { backscattering \& } \\
\text { fluorescence }\end{array}$ & l & $3 \mathrm{~W}$ & s & $\mathrm{M}, \mathrm{P}, \mathrm{T}$ & HOBI Labs, www.hobilabs.com \\
\hline $\begin{array}{l}\text { ECO VSF } \\
\text { backscattering meter }\end{array}$ & I & 85 mA @ 12-15 VDC & s & $\mathrm{M}, \mathrm{P}$ & Wet Labs, www.wetlabs.com \\
\hline Turbidity meter & I & $\begin{array}{l}6 \text { mA peak } \\
\text { @ 7-20 VDC }\end{array}$ & s & $\mathrm{M}, \mathrm{P}$ & Seapoint Sensors, www.seapoint.com \\
\hline $\begin{array}{l}\text { FASTtracka } \\
\text { fast repetition } \\
\text { rate fluorometer }\end{array}$ & I & $0.5 \mathrm{~A} @ 18-72$ VDC & s & $\mathrm{M}, \mathrm{T}, \mathrm{P}, \mathrm{S}$ & Chelsea Technologies, www.chelsea.co.uk \\
\hline $\begin{array}{l}\text { bbe FluoroProbe } \\
\text { multispectral } \\
\text { fluorometer }\end{array}$ & I & & s & M,P,T,A & bbe Moldaenke GmbH, www.bbe-moldaenke.de/ \\
\hline $\begin{array}{l}\text { OCR-504 } \\
\text { multispectral } \\
\text { irradiance meter }\end{array}$ & I & $25 \mathrm{~mA}$ at $9 \mathrm{VDC}$ & s & $M, D, A, G, P, T, S$ & Satlantic, www.satlantic.com \\
\hline $\begin{array}{l}\text { HyperOCR } \\
\text { hyperspectral } \\
\text { irradiance meter }\end{array}$ & I & $2 \mathrm{~W}$ at $18-72 \mathrm{VDC}$ & s & $\mathrm{M}, \mathrm{T}, \mathrm{S}$ & Satlantic, www.satlantic.com \\
\hline $\begin{array}{l}\text { BIS } \\
\text { multispectral } \\
\text { scalar irradiance } \\
\text { meter }\end{array}$ & I & $2 m A$ per channel & s & $M, D, A, P, T, S$ & Biospherical, www.biospherical.com \\
\hline $\begin{array}{l}\text { GLOWtracka } \\
\text { bioluminescence }\end{array}$ & I & 40 mA @ 12 VDC & s & M,T,P & Chelsea Technologies, www.chelsea.co.uk \\
\hline
\end{tabular}


Seapoint Sensors, uses similar technology. All sample more frequently than once per second. The use of wiper blades to reducing fouling on the optical windows and the use of copper foil in the vicinity of the windows and blades have met with some success in reducing biofouling.

Fluorescence is not strictly an IOP or AOP, but different aspects of fluorescence can be measured by both active and passive sensing systems. The principle underlying fluorescence is straightforward: $F=E^{*} a^{*} \phi$, where $F$ is fluorescence, $E$ is irradiance of the excitation light source, $a$ is the absorption coefficient of phytoplankton photosynthetic pigments and $\phi$ is the fluorescence quantum yield. If $E$ and $\phi$ are constant, then fluorescence is directly proportional to the absorption coefficient-itself a function of phytoplankton biomass or CDOM concentration, depending on the wavelengths selected. Chlorophyll fluorescence as a phytoplankton biomass proxy has a long history of measurement in the ocean. Lorenzen (1966) obtained the first continuous profiles of chlorophyll fluorescence by attaching a submerged pump to the end of a garden hose and pumping water to an on-deck fluorometer, sometimes with shocking results. Fortunately the technology evolved, and fluorometers were placed in pressure cases, integrated with the then-evolving CTDs, and lowered through the water column to directly obtain profiles of chlorophyll fluorescence. The first in situ fluorometers were large both in size and power consumption; modern fluorometers are at least an order of magnitude smaller in both. Two basic types of fluorometers in use today are pumped flow-though models, where excitation and detection occur inside the instrument and non-pumped models with flush-mounted optical windows, where excitation and detection occur in a volume external to the sensor that is potentially exposed to sunlight. Variability in the ratio of fluorescence to phytoplankton chlorophyll and carbon make interpretation of fluorescence somewhat problematic. Instruments such as the Chelsea FASTtracka fast repetition rate fluorometer (second generation soon to be released) use high intensity flashes to probe photosynthetic physiology. Fluorometers with strong UV excitation lamps have been used to detect CDOM, oil, tryptophan, and other organics. Small CDOM fluorometers with near UV excitation wavelengths show reasonable agreement with more conventional absorption measurements. Multi-spectral fluorometers, such as the bbe Fluoroprobe that can assess different algal groups based on excitation/ emission characteristics and multiple compounds (e.g., oil, CDOM), are becoming more available. Biofouling continues to be a concern for long-term deployments of fluorometers; however, copper tubing and shutters have been successfully used to extend deployment times.

AOP sensors are classified as functions of geometry and spectral characteristics. Three sensor geometries are cosine irradiance, $E_{d}$ or $E_{u}$ (proportional to the cosine of the incident upwelling or downwelling light); radiance, $\mathrm{L}$ (per steradian for a given solid angle, typically nadir); and scalar irradiance, $\mathrm{E}_{\mathrm{o}}$, (radiance over -4 pi steradians). PAR (photosynthetically available radiation) sensors are broadband and measure all photons between 400 and 700 $\mathrm{nm}$ with units of total quanta $\mathrm{m}^{-2}$ time $^{-1}$. Spectral sensors measure energy within specified narrow bandwidth in units of $\mathrm{W}$ $\mathrm{m}^{-2} \mathrm{~nm}^{-1}$. Multispectral sensors typically measure several to $\sim$ ten wavelengths, with options including UV, visible, and near IR wavelengths. Hyperspectral sensors cover the full spectrum, although bandwidth varys with specific instrument. The multispectral sensors are typically smaller with lower power consumption than the hyperspectral sensors. Specialized sensors, such as Biospherical's Natural Fluorometer that measures $\mathrm{Lu}$ at chlorophyll fluorescence wavelengths, or other monochromatic sensors are also available. Copper shutters have been successfully used to reduce biofouling of optical surfaces.

Bioluminescence can be considered as a special optical case, rather than as a strict IOP or AOP. Bioluminescence is the result of an exothermic internal chemical reaction that releases energy as light, either as an apparently spontaneous event or in response to mechanical stimulation. A subset of bacteria, dinoflagellates, zooplankton, and fish are bioluminescent; hence, the magnitude and spectra of bioluminescence are invaluable diagnostics of the presence and abundance of specific species. Bioluminescence is measured with very sensitive passive radiometers able to detect the very low light levels associated with night-time bioluminescence. The Chelsea GLOWtracker is primarily designed for dinoflagellate bioluminescence. Systems to detect, or stimulate and detect, bioluminescence from zooplankton remain research instruments.

\section{Optical imaging sensors}

A variety of different systems (Table 5) have been developed to image particles and organisms, ranging in size from small phytoplankton and marine snow up to small fish, with the ultimate goal of being able to remotely obtain taxonomic information on species based on pattern recognition algorithms. The Phido- $\varnothing$ is a two-dimensional imaging fluorometer that provides a highresolution image of phytoplankton and physical microstructure simultaneously (Franks and Jaffe, 2001). The free-falling camera has a $32 \times 32 \mathrm{~cm}$ field of view, with a $312 \mu \mathrm{m}$ resolution, and images undisturbed water in front of its path. The FlowCam (Fluid Imaging Technologies) is another system for phytoplankton that utilizes a continuously imaging flow cytometer with a particle resolution of $5-1000 \mu \mathrm{m}$. A submersible version is being transitioned for use on moorings up to $100 \mathrm{~m}$ deep to rapidly assess community structure, and provide particle counts and fluorescence and/ or scatter data. The Thin Laser Light Sheet Microscope (TLSM) is a relatively new prototype technology designed to image the distribution of microbial particles in a 3-dimensional fluid (Fuchs et al., 2002), which could yield insights into functional interactions within the microbial loop.

The Optical Plankton Counter (OPC) doesn't provide an image, but is a particle detector that uses optics to profile the crosssectional area of each particle in its beam path. The measured area is then related to an equivalent spherical diameter (ESD), 


\section{TABLE 5}

Current status of optical imaging sensors. Development stages, power [based on available information; watts (W), amps(A)] and deployment designations as in Table 1. Sampling time is sensor's processing time per sample in seconds (s), minutes (min), or hours

\begin{tabular}{|c|c|c|c|c|c|}
\hline Sensor & $\begin{array}{l}\text { Development } \\
\text { stage }\end{array}$ & Power & $\begin{array}{l}\text { Sampling } \\
\text { time }\end{array}$ & $\begin{array}{l}\text { Deployment } \\
\text { capability }\end{array}$ & $\begin{array}{l}\text { Source/ } \\
\text { contact }\end{array}$ \\
\hline $\begin{array}{l}\text { Phido-Phi } \\
\text { phytoplankton } \\
\text { camera }\end{array}$ & IV & $200 \mathrm{~W}$ & $2 \mathrm{~Hz}$ & $D, A, P, S$ & J. Jaffe, SIO, http://jaffeweb.ucsd.edu \\
\hline $\begin{array}{l}\text { LOPC } \\
\text { Laser Optical } \\
\text { Plankton Counter }\end{array}$ & III & $<20 W$ & S & $\mathrm{T}$ & www.brooke-ocean.com, www.focaltech.ns.ca \\
\hline $\begin{array}{l}\text { FlowCAM } \\
\text { microscope \& } \\
\text { flow cytometer }\end{array}$ & III & $20 \mathrm{~W}$ & S & $\mathrm{M}, \mathrm{S}$ & www.fluidimaging.com \\
\hline $\begin{array}{l}\text { Thin light } \\
\text { sheet laser } \\
\text { microscope }\end{array}$ & VI & $100 \mathrm{~W}$ & & $A, P$ & J. Jaffe, SIO, http://jaffeweb.ucsd.edu \\
\hline $\begin{array}{l}\text { VPR II } \\
\text { video camera }\end{array}$ & IV & $\begin{array}{l}2 \mathrm{~A} @ 48 \mathrm{VDC} ; \\
3 \mathrm{~A} @ 300 \mathrm{VAC}^{*}\end{array}$ & $117-750 \mathrm{ml} / \mathrm{s}$ & $\mathrm{M}, \mathrm{P}, \mathrm{T}$ & Seascan, Falmouth, MA \\
\hline $\begin{array}{l}\text { SIPPER2 } \\
\text { laser line-scan } \\
\text { camera }\end{array}$ & V & $\sim 100 \mathrm{~W}$ & $10 \mathrm{~L} / \mathrm{s}$ & $A, T, R$ & $\begin{array}{l}\text { B. Flanery, USF-COT } \\
\text { wflanery@marine.usf.edu }\end{array}$ \\
\hline $\begin{array}{l}\text { SIPPER3 } \\
\text { laser line-scan } \\
\text { camera }\end{array}$ & VII & $20-60 \mathrm{~W}$ & $15 \mathrm{~L} / \mathrm{s}$ & $\mathrm{M}, \mathrm{A}, \mathrm{P}, \mathrm{T}, \mathrm{R}$ & B. Flanery, USF, wflanery@marine.usf.edu \\
\hline $\begin{array}{l}\text { OceanCam } \\
\text { deep-ocean camera }\end{array}$ & I & $12-15$ volts & s & $\mathrm{M}, \mathrm{T}$ & Southampton Oceanography Centre \\
\hline $\begin{array}{l}\text { UVP } \\
\text { video camera }\end{array}$ & IV & & $25 \mathrm{~Hz}$ & $\mathrm{P}, \mathrm{S}$ & www.obs- vlfr.fr/ pvm/indeng.html \\
\hline $\begin{array}{l}\text { ZOOVIS-SC } \\
\text { camera with } \\
\text { strobed light sheet }\end{array}$ & V & $34 \mathrm{~W}$ & s & M & M. Benfield, LSU, mbenfie@Isu.edu \\
\hline
\end{tabular}

which is derived by equating the measured area to that of a circle and then extracting its diameter. OPCs are widely used to rapidly estimate zooplankton biomass (Herman, 1992; Woodd-Walker et al., 2000; Zhang et al. 2000), but species cannot be determined. The next generation Laser Optical Plankton Counter (LOPC) is smaller, reduces coincident particle counts, and is reported to be able to resolve higher plankton densities as well as measure shape outlines of particles $>1 \mathrm{~mm}$ ESD. Particle profiles $(100 \mu \mathrm{m}-35 \mathrm{~mm})$ can be generated at flow rates up to 12 knots (Brooke Ocean Technology Ltd.). The strengths and weaknesses of the OPC and LOPC sensors and their use on different platforms are reviewed in a workshop report (Zhou and Tande, 2002). To date the OPC and LOPC have been used primarily on towed vehicles or in free-fall. The LOPC is currently being transitioned for use on mobile platforms by $\mathrm{D}$. Checkley and R. Davis (SIO).
The Video Plankton Recorder (VPR, Davis et al., 1996) is an imaging system for particulates, phytoplankton, and zooplankton that uses forward scattered light. Recent configurations include a high-speed towed unit (VPRII), an autonomous battery-operated system for deployment on a CTD rosette (AutoVPR), a miniature system integrated into the AUV REMUS, and a moored profiling system (AVPPO, see below). The current VPR optics employ a highresolution digital camera and a synchronized strobe sampling at $60 \mathrm{~Hz}$. Depending on the optical configuration of the VPR, it can image $10 \mu \mathrm{m}-2.5 \mathrm{~cm}$ organisms, with an image volume of $117-750 \mathrm{ml}$, providing a sampling rate of $210-1350 \mathrm{~L} / \mathrm{min}$. The sample volume is upstream of the camera to minimize disturbance and uses specialized image-processing routines to identify planktonic taxa in real-time (Tang et al., 1998; Davis et al., submitted; Fig.1). The automated classification method is sufficiently accurate for estimating abundance patterns of dominant major taxa, but not for less abundant taxa. The range in overall accuracy is $61-79 \%$ for $4-7$ taxa, with accuracies for individual taxa ranging between $45-$ $91 \%$. Classification error is small relative to natural variability in abundance of dominant taxa. The VPRII and AutoVPR are rated for $500 \mathrm{~m}$ depth and the AVPPO is currently being used for extended deployments on a near-shore profiling mooring from $100 \mathrm{~m}$ (see below). In addition, threedimensional imaging and plankton tracking relative to turbulence is now possible with a 3D-VPR deployed on ROVs (Gallager et al. 2004).

Another approach is the Shadowed Image Particle Profiling and Evaluation Recorder (SIPPER), which uses two high-speed digital laser line-scan cameras that record continuous images of organisms in two dimensions in water flowing through a $96 \mathrm{x}$ $96 \mathrm{~mm}$ sampling tube (Samson et al. 2001; 


\section{FIGURE 1}

The Video Plankton Recorder (VPR) II on a high-speed towed vehicle is shown on the deck of the R/V Oceanus, along with some images collected on a cruise across the Atlantic Ocean.

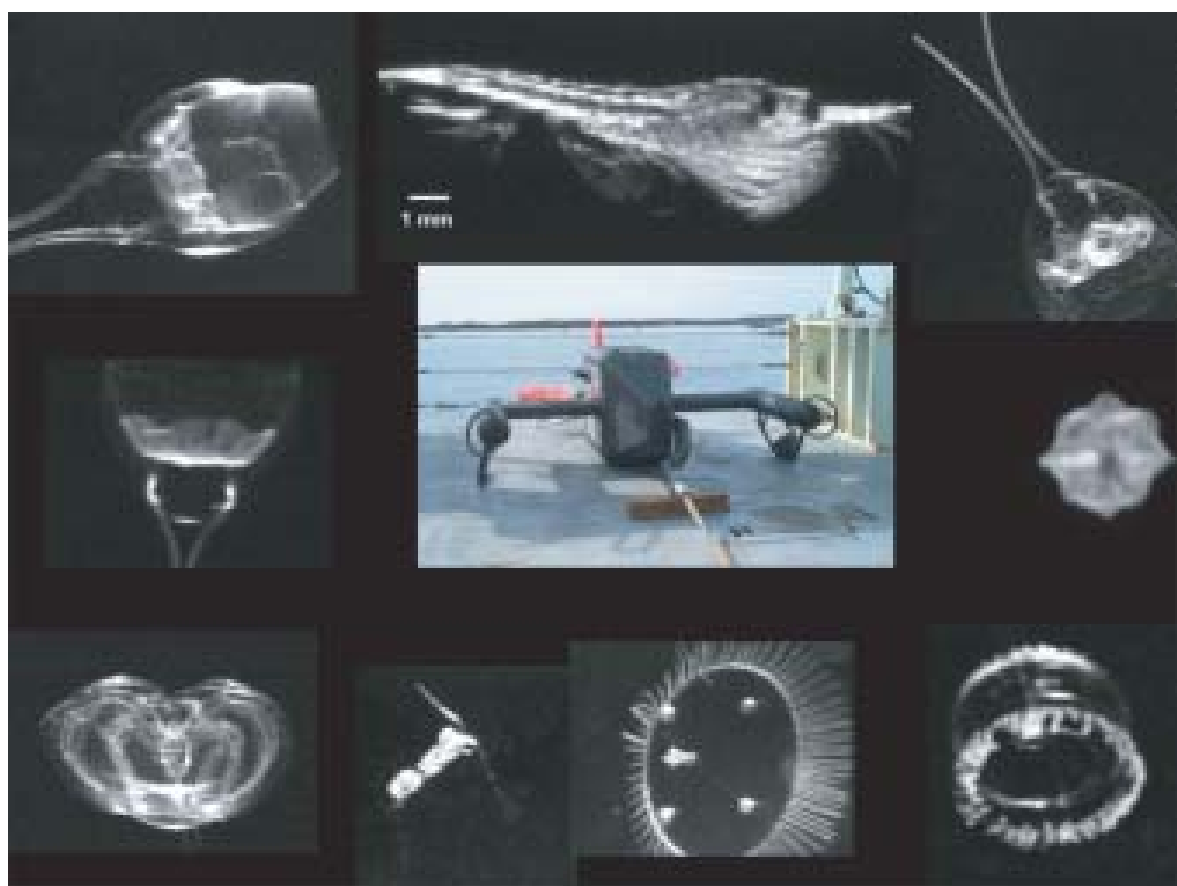

ates to $250 \mathrm{~m}$; Benfield et al. 2003) have been used in profiling mode and could be transitioned for use on moorings. Cameras, such as the OceanCam (Southampton Oceanographic Centre), also have been developed for time-lapse photography of deepsea biology and sedimentary processes. The OceanCam can operate at $6000 \mathrm{~m}$ depth for over a year on moorings. Other efforts to improve image recognition include the Zooscan software that recently became commercially available (www.zooscan.com) and is intended for automated analyses of preserved net samples.

\section{Acoustic sensors}

Bioacoustics (transmitted sound/active mode) is a cost-effective, efficient, and essential tool that can provide unique insights into the behavior and spatial and temporal variability of biological populations on many scales. Quantitative interpretation of acoustic backscattering, however, remains a chal-
Remson et al., 2004). Organisms between $15 \mu \mathrm{m}$ and 10's of $\mathrm{cm}$ may be imaged. The benefits of this technology are the larger sampling area and the ability to image large organisms, such as siphonophores, entirely intact (Fig. 2). Highly mobile organisms, however, such as large shrimps, may not be quantitatively assessed owing to avoidance; a problem common to all imaging systems. This system has been towed off ships and used on an AUV. Current modifications include improvements to the image recognition software (currently 70 - 75\% accuracy for 46 classifications in highly diverse tropical systems, Luo et al., 2004; Tang et al., in press), changing the configuration so that it can be used on moorings or in profiling mode, and enhancing the hardware so that it can operate to $1000 \mathrm{~m}$ (B. Flanery, personal communication). Other camera imaging systems, such as the Underwater Video Profiler (UVP, images 1.3 - 70 L, operates to $1200 \mathrm{~m}$; Gorsky et al., 2000) and the Zooplankton Imaging and Visualization System (ZOOVIS; $50 \mu \mathrm{m}$ resolution, $12 \mathrm{~cm}$ field of view, strobed light sheet for illumination of targets in focus, oper-

\section{FIGURE 2}

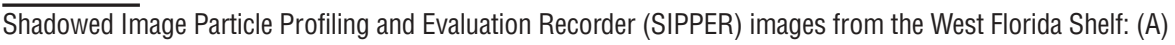
spumellarian radiolarian, (B) doliolid, (C) chaetognath, (D) mantis shrimp larvae, (E) lobate ctenophore, (F) cyclopoid copepod Oithona sp., (G) poecilostomatoid copepod Copilia, (H) calanoid copepod, (I) cnidarian: hydrozoa cf Obelia, (J) physonect siphonophore (images courtesy of A. Remson).
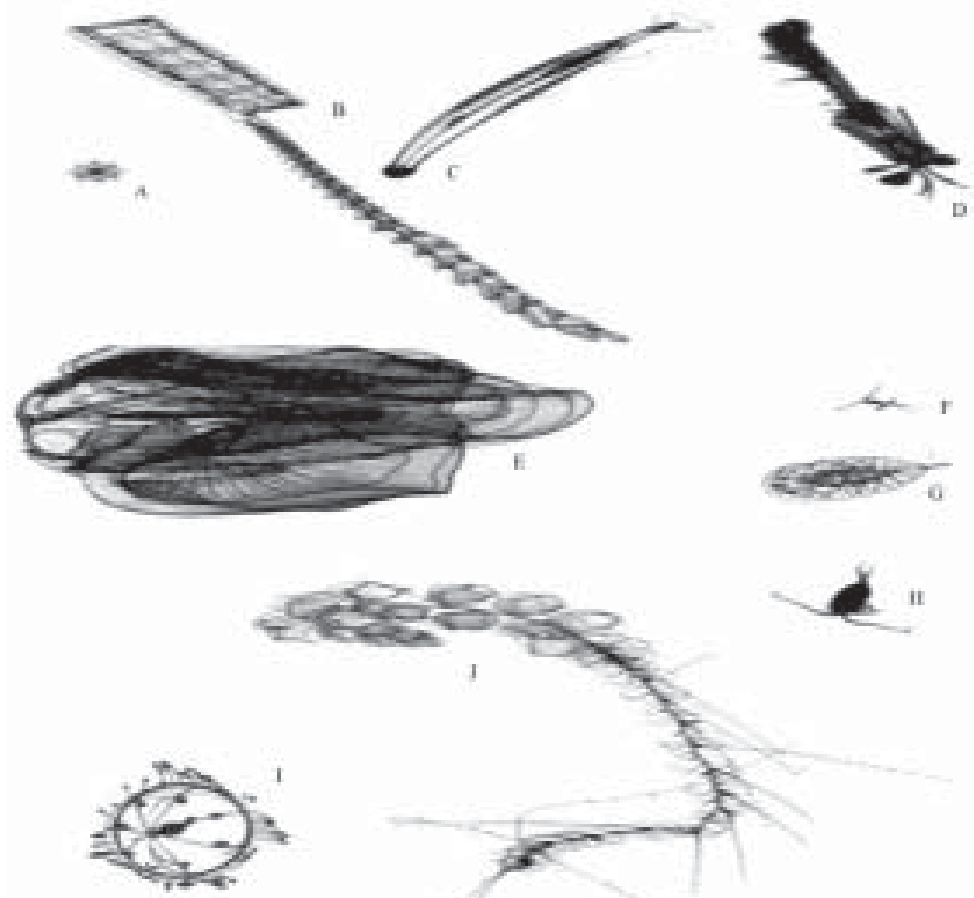

time 


\section{TABLE 6}

Current status of acoustic and microbial sensors and sampling systems. Development stages, power [based on available information; watts(W), amps(A)] and deployment designations as in Table 1. Sampling time is sensor's processing time per sample in seconds (s), minutes (min), or hours

\begin{tabular}{|c|c|c|c|c|c|}
\hline Sensor & $\begin{array}{l}\text { Development } \\
\text { stage }\end{array}$ & Power & $\begin{array}{l}\text { Sampling } \\
\text { time }\end{array}$ & $\begin{array}{l}\text { Deployment } \\
\text { capability }\end{array}$ & $\begin{array}{l}\text { Source/ } \\
\text { contact }\end{array}$ \\
\hline \multicolumn{6}{|l|}{ Acoustics } \\
\hline EK60 & I & $50-100 \mathrm{~W}$ & s & $\mathrm{A}, \mathrm{T}, \mathrm{S}$ & Simrad (split beam) www.simrad.com \\
\hline EK2000 & I & $<250 \mathrm{~W}$ & s & $A, T, R, S$ & Simrad (200kHz Multibeam) \\
\hline TAPS & I & $8.4 \mathrm{~W}$ & s & $\mathrm{M}, \mathrm{P}, \mathrm{T}$ & www.aard.tracor.com/home/eco/MarEco.html \\
\hline BIOSPAR & V & $35 \mathrm{~W}$ & s & $M, D$ & P. Wiebe, WHOI～～pwiebe@whoi.edu \\
\hline $\begin{array}{l}\text { FishTV } \\
\text { multibeam } \\
\text { (435 kHz, 1.6 Mhz) }\end{array}$ & IV & $500 \mathrm{~W}$ & $4 \mathrm{~Hz}$ & S & J. Jaffe, SI0～jules@mpl.ucsd.edu \\
\hline Acoustic tags & I & $7-360$ days $^{*}$ & s & Fish & $\begin{array}{l}\text { Hydroacoustic Technology Inc. } \\
\text { www.htisonar.com }\end{array}$ \\
\hline Acoustic tags & 1 & up to 191 days* & s & $\begin{array}{l}\text { Fish, } \\
\text { invertebrates, } \\
\text { mammals }\end{array}$ & VEMCO, www.vemco.com \\
\hline $\begin{array}{l}\text { Archival tags } \\
\text { temp, salinity, } \\
\text { pressure }\end{array}$ & I & 5 years $^{\dagger}$ & s & $\begin{array}{l}\text { Fish, birds, } \\
\text { mammals }\end{array}$ & Star-0ddi, www.star-oddi.com \\
\hline $\begin{array}{l}\text { Microbial } \\
\text { Environmental } \\
\text { Sample } \\
\text { Processor (ESP) }\end{array}$ & V & $3-4 \mathrm{~W}$ & min-hours & M, D, S & $\begin{array}{l}\text { C. Scholin, MBARI } \\
\text { scholin@mbari.org }\end{array}$ \\
\hline $\begin{array}{l}\text { Aqua Monitor } \\
\text { smart water sampler }\end{array}$ & I & 2-740 mA @9-15 & & $\mathrm{M}, \mathrm{A}, \mathrm{T}$ & $\begin{array}{l}\text { WS EnviroTech } \\
\text { www.wsenvirotech.com } \\
\end{array}$ \\
\hline
\end{tabular}

lenge, particularly for zooplankton (Griffiths et al., 2002). Continuing efforts in sensor validation, model development, and analytical methodology are urgently needed. A number of other issues remain including noise effects, separating backscattering due to turbulent microstructure from that of biological origin, a better understanding of how animal density, size, and shape influence target strength variability, and improved knowledge of model parameters, such as soundspeed and density contrasts.

Most acoustic systems are mounted on the hulls of ships, towed, or used in profile mode alongside ships, but a few have transitioned to other platforms. A SIMRAD EK500 echosounder (Table 6) was successfully deployed in the AUV Autosub-2 in the Southern Ocean (Brierley et al., 2002). Fernandes et al. (2003) review the use of mobile platforms for fisheries acoustics and note that advances in power-source technology are needed to extend operational ranges. Limitations due to the size/weight of transducer ceramics, especially at low frequencies, may soon be offset by advances in broadband and multibeam sonar. The Tracor Acoustic Profiling System (TAPS) is an example of a multi-frequency echosounder, which is being used on moorings in upward, downward, or horizontal mode. It can operate in combination with real-time telemetry for remote control of some parameters for durations up to 6 months depending on battery support (Holliday et al., 2003). The Bioacoustic Sensing Platform and Relay (BIOSPAR, Wiebe et al., 1995) was deployed for short periods (days - weeks) on a mooring and a free drifter using two downward-looking dual-beam transducers. Battery design included photovoltaic solar collectors that could provide power to the system for over a month even without additional sunlight. Several other laboratories are currently developing systems for use on moorings that could be available for observatories in a few years. One such model is the FishTV, a three-dimensional acoustic imaging system, which obtains acoustic and optical images simultaneously for information on target species and behavior (Jaffe et al., 1998; J. Jaffe, personal communication).
Acoustic Doppler Current Profilers (ADCP), typically used to profile water velocity on ships and moorings, also have been used to assess zooplankton backscatter.Until recently, however, $\mathrm{ADCPs}$ were not rigorously calibrated and therefore the volume backscattering data could not be converted to abundance or biomass. New methods may enable more quantitative results making these a lower cost alternative for some programs. In addition, $\mathrm{ADCPs}$ can provide information on zooplankton vertical migration rates (Heywood, 1996) and swimming behavior within aggregations (e.g., Zhou and Dorland, in press).

A different use of active acoustics (Table 6) employs marine mammals and fishes as mobile platforms using ultrasonic telemetry (e.g., Voegeli et al., 2001). Archival tags attached to the animals gather environmental and spatial information and may monitor physiological parameters, which are transmitted to fixed benthic recorders, buoys, or satellite receivers. Passive acoustic recording packages also are deployed on moorings or as sonobuoys to estimate population abun- 
dances from calling patterns of marine mammals and fishes for up to a year (McDonald et al., 1995).

\section{Microplankton sensors and sampling systems}

Microbial populations are particularly difficult to assess in marine systems as direct visualization and culturing of organisms does not distinguish the entire spectrum of species present in the environment. Many different groups are working on techniques for automated species-level identification using molecular probes. Genomic sensors hold tremendous promise, but are in an early stage of development. One such autonomous genosensor that is currently being tested uses a microfluidics system and nucleic acid sequenced based amplification technology to detect a range of organisms in situ, such as the red tide species, Karenia brevis, Synechococcus, and human enteroviruses (Smith et al., 2004).

Sampling systems, which can perform a variety of activities such as sample collection, pretreatments, dilution, concentration, filtration, extraction, and bubble concentration are urgently needed for in situ applications. The Environmental Sample Processor (ESP) is being developed to detect multiple microorganisms using molecular probe technology, as well as perform sample collection, concentration, different analyses, and sample archival (Scholin et al., 1998). The ESP is in a period of transition from prototype and short-term deployments to development and application of a "second generation" unit that will be wettested later this year. The current design is aimed for mooring deployments at depths up to $4,000 \mathrm{~m}$, but could potentially be used on an AUV or a drifter in future years (C. Scholin, personal communication). Another laboratory working on innovative ways to accomplish automated sample treatments has a prototype system that can characterize particle density, size, and chemical composition in a particle suspension, then concentrate or dilute the sample as needed (L. García -Rubio, personal communication). This system has been demonstrated for in situ identification and clas- sification of pathogens (Alupoaei et al., 2004) and other microorganisms, such as Cryptosporidium and Giardia (Callahan et al., 2003). A number of challenges, however, must be overcome before a sophisticated sampling system will be suitable for remote use in the oceans. One of the few commercially available samplers is the Aqua Monitor (WS EnviroTech). This is a relatively simple plankton collection system (50 discrete/100 - $1000 \mathrm{ml}$ samples) that has been successfully deployed for a year collecting weekly samples and can be used on a variety of platforms.

\section{Sensors and Samplers for Studying Seafloor Hydrothermal Systems and Cold Seeps}

Over the past decade, a number of sensors and samplers have been developed to investigate the spatial and temporal variability of fluids venting at high temperature seafloor vent sites and at cold seeps. While many of the issues related to sensor development in these environments are similar to those for other ocean environments (e.g., calibration, biofouling, instrument drift), others are specific to the harsh chemical (e.g., low pH, high sulfide, high metal, volatile-rich) and thermal (temperatures $>400^{\circ} \mathrm{C}$ ) conditions. An added complication when transitioning the sensors/ samplers from in situ to long-term use is the dynamic nature of the environments. This includes biofouling (specifically colonization of instruments by organisms as large as $\mathrm{mm}$ to $\mathrm{cm}$ in size), perturbation of the environment (particularly at cold seeps) in low temperature areas, corrosion, deposition of minerals, and possible incorporation of the instrument into the growing vent deposit at high temperature locations. The need for in situ and long-term measurements within these environments has been recognized (see Seyfried et al., 2001; Gallager and Whelan, 2004) and considerable progress is being made. The current status of sensors and samplers is shown in Table 7.

\section{High temperature vents}

For the high temperature environment (in acidic, $>300^{\circ} \mathrm{C}$ fluids), there are several sensors now capable of making in situ measurements (e.g., $\mathrm{H}_{2}, \mathrm{H}_{2} \mathrm{~S}, \mathrm{pH}$, resistivity (as a proxy for $\mathrm{Cl}$ )). Of these the resistivity sensors have been successfully deployed for greater than one month within hot vent orifices (Lilley et al., 2000). The other sensors have worked in situ and are currently being modified for long-term deployment at high temperatures (Ding et al., 2001, in prep; M. Lilley, personal communication). Modifications are also underway for long-term use of some of these sensors in lower temperature areas (e.g., the $\mathrm{H}_{2} / \mathrm{H}_{2} \mathrm{~S}$ sensor has worked successfully for 13 days within a Riftia colony (W. Seyfried, personal communication).

There are also a number of "incubator" type instruments for use at high temperature vents, that are constructed of titanium and use Ti sheathed thermocouples or Resistive Temperature Detectors (RTD). These instruments are capable of temperature measurements in situ within sampling chambers or within actively forming deposits, and allow recovery of materials (minerals and associated microorganisms) from areas of known temperature history (e.g., Reysenbach et al., 2000; Tivey et al., 2003; E. Dunn, personal communication; D. Kelley personal communication).

A few instruments are being developed for use at high temperature vents that are noninvasive, e.g., ALISS (measures ambient light emission) and DORISS (laser Raman spectrometer). Laser induced breakdown spectroscopy (LIBS) is also a possible technique that is being investigated for non-invasively (or semi-invasively) measuring elemental concentrations of some elements within high temperature vent fluids (A. Chave, S.M. Angel, personal communication).

Another technique that has been used successfully to examine long-term variability within moderate to high temperature fluids, involves intermittent or continuous sampling of hot fluids into the cooler ambient temperature environment, with addition of acid during sampling, and storage in cooler regions on the seafloor (Wheat et al., 2000; Kadko et al., 2000). The McLane Remote 


\section{TABLE 7}

Current status of vent and seep sensors/samplers. Development stages, power [watts(W), amps(A), volts(V)] and deployment designations as in Table 1, except la is commercially available but not modified for long-term deployment and IVa is operational in situ but not modified for long-term deployment. Sampling time is sensor's processing time per sample in seconds (s), minutes (min), or hours

\begin{tabular}{|c|c|c|c|c|c|}
\hline Sensor & $\begin{array}{l}\text { Development } \\
\text { stage }\end{array}$ & Power & $\begin{array}{l}\text { Sampling } \\
\text { time }\end{array}$ & $\begin{array}{l}\text { Deployment } \\
\text { capability } / \mathrm{T}^{\circ} \mathrm{C} \text { range }\end{array}$ & Source/contact \\
\hline Temperature (RTD) & I & & S & $\mathrm{R} / 0-400+^{\circ} \mathrm{C}$ & Onset computer; DeepSea Power and Light \\
\hline $\begin{array}{l}\mathrm{pH}(\mathrm{YSZ} \text { ceramic, } \\
\left.\mathrm{Ir} / \mathrm{IrO}_{2}, \mathrm{Ti} / \mathrm{TiO}_{2}\right)\end{array}$ & III & $10^{-1} \mathrm{~W}$ & s & $\mathrm{R} / 10-400^{\circ} \mathrm{C}$ & W. Seyfried, K. Ding * \\
\hline Sulfide/ $\mathrm{H}_{2} \mathrm{~S}$ & III & $10^{-1} \mathrm{~W}$ & s & $\mathrm{R} / 10-400^{\circ} \mathrm{C}$ & W. Seyfried, K. Ding * \\
\hline $\mathrm{H}_{2}(\mathrm{Au})(\mathrm{Pt})$ & III & $10^{-1} \mathrm{~W}$ & & $\mathrm{R} / 10-400^{\circ} \mathrm{C}$ & W. Seyfried, K. Ding * \\
\hline $\mathrm{H}_{2}\left(\mathrm{Au}_{5} \mathrm{OPd} \mathrm{d}_{5} 0\right)$ & III & & s-hours & $\mathrm{R} / 20-400^{\circ} \mathrm{C}$ & $\begin{array}{l}\text { M. Lilley, UWashington } \\
\text { lilley@u.washington.edu }\end{array}$ \\
\hline $\begin{array}{l}\text { Resistivity } \\
\text { (proxy for } \mathrm{Cl} \text { ) }\end{array}$ & II & & s & R/lowT-400+ ${ }^{\circ} \mathrm{C}$ & $\begin{array}{l}\text { M. Lilley, UWashington } \\
\text { lilley@u.washington.edu }\end{array}$ \\
\hline $\begin{array}{l}\text { Temperature arrays } \\
\text { Ti sheathed } \\
\text { thermocouples }\end{array}$ & II & $10^{-2} \mathrm{~W}$ & s & $\mathrm{R} / 0-400+{ }^{\circ} \mathrm{C}$ & $\begin{array}{l}\text { A. Bradley/M.K. Tivey, WHOI } \\
\text { mktivey@whoi.edu }\end{array}$ \\
\hline $\begin{array}{l}\text { Mineral microcosm } \\
\text { temperature array }\end{array}$ & IV & $\begin{array}{l}9 \text { v up } \\
\text { to } 1 \text { year }\end{array}$ & s-hours & $\mathrm{R} / 0-400+{ }^{\circ} \mathrm{C}$ & $\begin{array}{l}\text { E. Dunn, Arizona State University } \\
\text { eedunn@asu.edu }\end{array}$ \\
\hline $\begin{array}{l}\text { Microbial incubator } \\
\text { separate } \\
\text { chambers/wafers }\end{array}$ & II & & s-hours & $\mathrm{R} / 0-360^{\circ} \mathrm{C}$ & $\begin{array}{l}\text { D. Kelley, UWashington } \\
\text { kelly@ocean.washington.edu }\end{array}$ \\
\hline $\begin{array}{l}\text { Vent cap in situ } \\
\text { growth chamber }\end{array}$ & ॥ & & $\mathrm{s}$ & $\mathrm{R} / 0->150^{\circ} \mathrm{C}$ & A-L. Reysenbach* \\
\hline $\begin{array}{l}\text { ALISS (Ambient } \\
\text { Light Imaging } \\
\text { Spectral System) }\end{array}$ & V & & $\mathrm{s}-\mathrm{min}$ & $\mathrm{R}$ & A. Chave/S. White * \\
\hline $\begin{array}{l}\text { DORISS (Deep } \\
\text { Ocean Raman } \\
\text { In Situ Spectrometer) }\end{array}$ & IVa & $420 \mathrm{~W}$ & s-min & $\mathrm{R} / 0-350^{\circ} \mathrm{C}$ & P. Brewer/S. White * \\
\hline Gamma detector & II & & s & $\mathrm{R} / 0-100^{\circ} \mathrm{C}$ & D. Kadko UMiami, dkadko@rsmas.miami.edu \\
\hline $\begin{array}{l}\text { InSpectr-MIMS } \\
\text { mass spectrometer }\end{array}$ & la & $<100 \mathrm{~W}$ & s-min & $\mathrm{M}, \mathrm{T}, \mathrm{A}, \mathrm{PO}-200^{\circ} \mathrm{C}$ & $\begin{array}{l}\text { G. Eaton, Applied Microsystems, Ltd. } \\
\text { greg@aml.bc.ca } \\
\text { R.T. Short/D. Fries, USF*tshort@marine.usf.edu }\end{array}$ \\
\hline $\begin{array}{l}\text { Mass SURFER - } \\
\text { rotating field } \\
\text { mass spectrometer }\end{array}$ & V & 8 W contin. & $\min$ & All $/ 0-400^{\circ} \mathrm{C}$ & G. McMurtry* \\
\hline $\begin{array}{l}\text { DeepQuad MIMS - } \\
\text { quadrupole } \\
\text { mass spectrometer }\end{array}$ & VI & $\begin{array}{l}100 \text { W peak; } \\
<1 \text { W standby }\end{array}$ & $\min$ & All $/ 0-100+{ }^{\circ} \mathrm{C}$ & $\begin{array}{l}\text { G. McMurtry, UHawaii } \\
\text { garym@soest.hawaii.edu }\end{array}$ \\
\hline $\begin{array}{l}\text { NEREUS - mass } \\
\text { spectrometer }\end{array}$ & V & & & $\mathrm{M}, \mathrm{T}, \mathrm{A} / 0-35^{\circ} \mathrm{C}$ & $\begin{array}{l}\text { R. Camilli, WHOI } \\
\text { rcamilli@whoi.edu }\end{array}$ \\
\hline $\begin{array}{l}\text { Gemini - mass } \\
\text { spectrometer }\left(\mathrm{CH}_{4}\right)\end{array}$ & VI & $30 \mathrm{~W}$ & s & $\mathrm{M}, \mathrm{T}, \mathrm{A} / 0-35^{\circ} \mathrm{C}$ & $\begin{array}{l}\text { R. Camilli, WHOI } \\
\text { rcamilli@whoi.edu }\end{array}$ \\
\hline Redox potential (Eh) & III & & S & $\mathrm{R}, \mathrm{A} / 0$ to $20^{\circ} \mathrm{C}$ & K. Nakamura* \\
\hline pH (glass electrode) & IVa & & $15 s$ & $\mathrm{R} / 0-120^{\circ} \mathrm{C}$ & N. Le Bris * \\
\hline $\begin{array}{l}\text { Sulfide/Fe/ } / \mathrm{NO}_{3} \\
\text { (Alchimist) }\end{array}$ & IVa & & $15 \mathrm{~s}$ & $\mathrm{R} / 0-30^{\circ} \mathrm{C}$ & N. Le Bris * \\
\hline $\begin{array}{l}\text { METS underwater } \\
\text { methane sensor }\end{array}$ & I & $160 \mathrm{~mA}$ & s-min & $\mathrm{R}, \mathrm{M}, \mathrm{P}, \mathrm{T} / 0-20^{\circ} \mathrm{C}$ & Capsum; www.asd-sensors.com/capsum.htm \\
\hline $\begin{array}{l}\text { Electrochemical } \\
\text { analyzer }\left(\mathrm{O}_{2}, \mathrm{H}_{2} \mathrm{~S} \text {, }\right. \\
\mathrm{FeS}, \mathrm{Fe}(\mathrm{II}) \\
\mathrm{Mn}(\mathrm{II}), \mathrm{Zn}(\mathrm{II}) \\
\mathrm{S}_{2} \mathrm{O}_{3}{ }^{2-}, \mathrm{S}_{x}{ }^{2-}\end{array}$ & III & & S & $\mathrm{R}, \mathrm{S}, \mathrm{P}, \mathrm{M} / 1.5-100^{\circ} \mathrm{C}$ & $\begin{array}{l}\text { G. Luther, UDelaware with Analytical } \\
\text { Instrument Systems, Inc. ais@aishome.com } \\
\text { luther@udel.edu }\end{array}$ \\
\hline $\begin{array}{l}\text { Scanner }\left(\mathrm{H}_{2} \mathrm{~S}, \mathrm{Si}\right. \\
\left.\mathrm{NO}_{3}, \mathrm{Mn}, \mathrm{Fe}\right)\end{array}$ & II & $24 \mathrm{~W}$ & $\sim 30 \mathrm{~s}$ & $\mathrm{R}, \mathrm{P} / 0$ to $20^{\circ} \mathrm{C}$ & $\begin{array}{l}\text { K. Johnson, MBARI } \\
\text { johnson@mbari.org }\end{array}$ \\
\hline
\end{tabular}




\begin{tabular}{|c|c|c|c|c|c|}
\hline Sensor & $\begin{array}{l}\text { Development } \\
\text { stage }\end{array}$ & Power & $\begin{array}{l}\text { Sampling } \\
\text { time }\end{array}$ & $\begin{array}{l}\text { Deployment } \\
\text { capability } / \mathrm{T}^{\circ} \mathrm{C} \text { range }\end{array}$ & Source/contact \\
\hline ZAPS (Mn, UV & & & & & G. Klinkhammer, \\
\hline Fluorescence) & & & & & OSUgklinkhammer@coas.oregonstate.edu \\
\hline $\begin{array}{l}\text { MCA-2000 (Si, } \\
\left.\mathrm{H}_{2} \mathrm{~S}\right)\end{array}$ & & & & & T. Gamo, UTokyo \\
\hline GAMOS (Mn) & & & & & T. Gamo, UTokyo \\
\hline $\begin{array}{l}\text { SUAVE (Mn, Fe, } \\
\left.\mathrm{H}_{2} \mathrm{~S}, \mathrm{pH}\right)\end{array}$ & & & & & G. Massoth* \\
\hline AIS $\left(\mathrm{H}_{2} \mathrm{~S}\right)$ & & & & & J. Radford-Knoery* \\
\hline $\begin{array}{l}\text { ISUS (HS-, Br-, } \\
\left.\mathrm{NO}_{3}, \mathrm{DOC}\right)\end{array}$ & I & $12 \mathrm{~W}$ & $0.5 \mathrm{~s}$ & $\begin{array}{l}\text { All/ } 0 \text { to } \sim 20^{\circ} \mathrm{C} \\
\text { to }>200^{\circ} \mathrm{C} \text { (but limited } \\
\text { HS- as } p H \text { drops) }\end{array}$ & $\begin{array}{l}\mathrm{NO}_{3} \text { : Satlantic / WETSAT, www.satlantic.com, Other: } \\
\text { K. Johnson, MBARI, johnson@mbari.org }\end{array}$ \\
\hline $\begin{array}{l}\text { OSMO Analyzer } \\
\text { (Fe; other } \\
\text { possible) }\end{array}$ & II & 100 uW contin. & $30 \mathrm{~min}$ & $\begin{array}{l}\text { M or benthic } \\
\text { deployment only; } \\
0 \text { to } 20^{\circ}\end{array}$ & $\begin{array}{l}\text { H. Jannasch/T. Chapin/K. Johnson, MBARI, } \\
\text { jaha@mbari.org }\end{array}$ \\
\hline OSMOSampler & II & & & $\mathrm{R} / 0->30^{\circ} \mathrm{C}$ & H. Jannasch/C.G. Wheat ${ }^{\star}$ \\
\hline $\begin{array}{l}\text { McLane Remote } \\
\text { Access Sampler }\end{array}$ & II & & & & $\begin{array}{l}\text { McLane Research Laboratories, Inc., } \\
\text { www.mclanelabs.com }\end{array}$ \\
\hline $\begin{array}{l}\text { McLane Water } \\
\text { Transfer System }\end{array}$ & II & & & & $\begin{array}{l}\text { McLane Research Laboratories, Inc., } \\
\text { www.mclanelabs.com }\end{array}$ \\
\hline $\begin{array}{l}\text { Medusa -flow rate, } \\
\text { transmissometry, } \\
\text { T, gas tight sampler }\end{array}$ & I & $\ll 1 \mathrm{~W}$ & s & $\mathrm{R} / 0-500^{\circ} \mathrm{C}$ & $\begin{array}{l}\text { Earth-ocean systems Ltd /or A. Schultz, OSU } \\
\text { adam@coas.oregonstate.edu }\end{array}$ \\
\hline
\end{tabular}

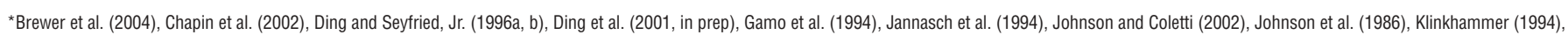

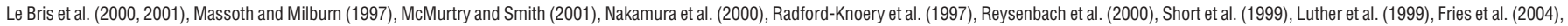
Wheat et al. (2000), White et al. (2002).

Access Sampler is capable of collecting 48 samples at predetermined intervals, while the OsmoSampler can make collections continuously for days to months. OsmoSamplers have been field tested on short term (days) to long term (years) deployments in a variety of environments, including boreholes, low temperature vents, high temperature vents, sediment (pore water profiles - harpoon style), moorings, and in estuarine settings (Jannasch et al. 2003, in press; Wheat et al., 2000, 2003). These samples allow study of the temporal variability of a number of elements, including $\mathrm{K}, \mathrm{Ca}, \mathrm{SO}_{4}^{2-}, \mathrm{Mn}, \mathrm{Ba}, \mathrm{Fe}, \mathrm{Cl}, \mathrm{Mg}$, Si.

\section{Low temperature vents and cold seeps}

A greater diversity of sensors and longterm samplers is currently available for use in the lower temperature environments at vent sites and cold seeps. These include sensors that can measure $\mathrm{pH}$ using an electrode, and $\Sigma S$, HS, Fe, nitrate, nitrite, $\mathrm{O}_{2}$, $\mathrm{Fe}, \mathrm{S}, \mathrm{Mn}, \mathrm{Zn}, \mathrm{Si}, \mathrm{CH}_{4}, \mathrm{Br}^{-}$, and $\mathrm{DOC}$ at temperatures from ambient to $20^{\circ} \mathrm{C}$, and in some cases to $100^{\circ} \mathrm{C}$, using a variety of techniques including conventional flow analysis, flow injection analysis, colorimetry, chemiluminescence, voltametric detection, and UV detection (see Table 7 and references therein). Mass spectrometers for use in situ also are being developed (Short et al., 1999, 2001; McMurtry and Smith, 2001; Fries et al., 2004). Although their power requirements are relatively high, mass spectrometers provide panoramic measurement capabilities and, perhaps at times, superior yields of "information per Watt" than single analyte sensors. One design, based on development work at the University of South Florida, is commercially available from Applied Microsystems, Ltd. (Table 7).

Long-term samplers that have been used in low temperature environments include continuous OsmoSamplers (that collect -1 to $50 \mathrm{ml} /$ week), the McLane Remote Access Sampler that collects up to $48-100$ to $500 \mathrm{ml}$ samples at pre-timed intervals, the McLane Water Transfer System that collects particulates by filtering up to 24 samples at pre-timed intervals, and the Medusa system that measures temperature, flow rate, and transmissometry, and collects 6-120 $\mathrm{ml}$ Ti gas tight samples at pre-timed intervals (Table 7 and references therein).

\section{Needs}

Several key areas require focused attention for low temperature environments, including the development of biological sensors and samplers, such as the Environmental Sample Processor (see above and Table 6), and transition of existing sensors and samplers for longer-term deployments to allow monitoring. A list of desired sensors for measuring various parameters, and the levels of desired range and sensitivity, is given in Table 8 (Gallager and Whelan, 2004). In high temperature environments, continued development of existing sensors, transition of these sensors for long-term deployment, and development of sensors that measure other parameters (e.g., metals, $\mathrm{CO}_{2}, \mathrm{CH}_{4}$, organic species) are needed. In situ sensors are necessary because fluid species change and metals 
precipitate when removed from the pressure/ temperature conditions within vents. Highfrequency sampling is required to investigate both short and long-term variability in local and sub-surface processes. Other issues complicate the transition from short to longterm in situ observation, such as the harsh $\mathrm{pH}$ and temperature conditions of the fluids and the dynamic nature of the vent (e.g., the vent opening can migrate over time). Solutions to this problem include building sensors that are planned for incorporation into a growing vent structure, or building sensors with time-limited exposure to the hot fluid. For the latter case, a robotic device could be used to locate the vent orifice (e.g., using an infrared sensor), allowing the sensor to be placed within the flow and then removed (Gallager and Whelan, 2004).

\section{Integrated Sensing Systems}

Integration of sensors into functional instruments, which address specific scientific questions, is seen as an essential step toward providing a multi-disciplinary and a multiscale context to the measurements made by observatories. Examples of such systems include the Autonomous Vertically Profiling Plankton Observatory (AVPPO), which is currently deployed at the Martha's Vineyard Coastal Observatory (MVCO, http:// 4dgeo.whoi.edu/vpr), the Gulf of Maine
Ocean Observing System (GoMOOS; www.gomoos.org/), the Coastal Ocean Observation Lab (COOL; http:// marine.rutgers.edu/cool/LEO/ LEO15.html), the Physical Oceanographic Real-Time System (PORTS; http:// ompl.marine.usf.edu/PORTS/index.html ), and the Coastal Ocean Monitoring and Prediction System (COMPS; http:// comps.marine.usf.edu/). The AVPPO, which is the most biologically focused, has been operational for about three years semi-continuously and was designed for use in coastal regions up $100 \mathrm{~m}$ depth with currents up to ca. 4 kts. The AVPPO is driven by an underwater winch coupled with an electromechanical system for sampling the water column from the air-water interface to the seafloor. It provides a real-time data stream from a variety of biological, bio-optical, hydrographic and physical sensor systems. These data are synthesized and visualized on a web-based display and data archive. The AVPPO profiling package carries the following sensors: a Seascan, a VPR to quantify large phytoplankton, micro and meso-zooplankton, and marine snow; a Wet Labs transmissometer, chlorophyll fluorometer, and CDOM fluorometer; a PAR downwelling light sensor, Sea Bird conductivity and temperature sensors; a Wet Labs ac-9 absorption spectrometer; roll, pitch, yaw sensors; a Satlantic 7 channel OCR200 radiance sensor; a Satlantic 7 channel

\section{TABLE 8}

Vents and seeps sensor wish list*

\begin{tabular}{|c|c|c|}
\hline \multicolumn{3}{|c|}{ Vents and seeps sensor wish list* } \\
\hline Parameter/Species & Optimal Ranqe & Sensitivity \\
\hline \multirow{2}{*}{ Temperature $\left({ }^{\circ} \mathrm{C}\right)$} & $0-400\left({ }^{\circ} \mathrm{C}\right)$ & \pm 0.5 units \\
\hline & $0-3\left({ }^{\circ} \mathrm{C}\right)$ & \pm 0.001 units \\
\hline pH (general) & $2-10$ & \pm 0.1 units \\
\hline $\mathrm{pH}\left(\mathrm{CO}_{2}\right)$ & $5-8$ & \pm 0.001 units \\
\hline $\mathrm{H}_{2} \mathrm{~S}, \mathrm{H}_{2}, \mathrm{CH}_{4}$ & $1-10 \mathrm{nmol} / 10-100 \mathrm{mmol}$ & $2-5 \%$ \\
\hline $\mathrm{CO}_{2}$ & $2-100 \mathrm{mmol}$ & $2-5 \%$ \\
\hline $\mathrm{Cl}^{2}$ & $30-1000 \mathrm{mmol}$ & $2-5 \%$ \\
\hline $\mathrm{Fe}^{2+}, \mathrm{Fe}^{3+}, \mathrm{Mn}$ & $1 \mathrm{nmol}-25 \mathrm{mmol}$ & $2-5 \%$ \\
\hline $\mathrm{O}_{2}$ & $0-250 \mu \mathrm{mol}$ & $2-5 \%$ \\
\hline $\mathrm{NO}_{3}^{-}$ & $0-40 \mu \mathrm{mol}$ & $2-5 \%$ \\
\hline $\mathrm{NH}_{4}^{+}$ & $10 \mathrm{nmol}-10 \mathrm{mmol}$ & $2-5 \%$ \\
\hline $\mathrm{NO}_{2}^{-}, \mathrm{N}_{2} \mathrm{O}$ & $0-4 \mu \mathrm{mol}$ & $2-5 \%$ \\
\hline $\mathrm{SO}_{4}^{2-}$ & $1 \mathrm{nmol}-1 \mathrm{mmol}$ & $2-5 \%$ \\
\hline Organics, $C_{1}-C_{5}$ & Not presently established & $2-10 \%$ \\
\hline Metals, $\mathrm{Cu}, \mathrm{Zn}, \mathrm{As}, \mathrm{Pb}, \mathrm{Co}$ & Not presently established & $2-10 \%$ \\
\hline
\end{tabular}

*from Gallager and Whelan (2004)
OCI200 irradiance sensor; an Aanderaa optode oxygen sensor; an Imagenics 881a sector scanning sonar for observing fish; a WHOI-built bioluminescence sensor (Solid State Bathy Photometer), and a MAV-3 time of flight Doppler Velocimeter (NOBSKA Associates). An uplooking $300 \mathrm{KHz}$ ADCP is mounted on the winch frame and the addition of a Satlantic nitrate sensor is planned. Currently, the observatory is serviced about once every 4 to 6 weeks using a small boat, at which time optical windows and sensors are cleaned and the ac- 9 is calibrated. Biofouling within the pumped water lines for the CTD, ac-9, fluorometers, and oxygen optode is eliminated by using copper tubing where logistically possible. Copper shutters will be installed on the optical windows this year.

\section{New Directions}

Numerous emerging technologies and analytical techniques show great promise for marine applications. In the following section we highlight a few of these new approaches that would benefit from accelerated development for use by observatories. The Laser Induced Breakdown Spectroscopy (LIBS, www.arl.army.mil/wmrd/ LIBS), mentioned above, utilizes a pulsed laser to create a microplasma on the material of interest then a spectrophotometer captures the transient light to identify and quantify elements. It is an inexpensive analytical technique that can be used on solid, liquid or gaseous phases. Its sensitivity to all elements remains to be tested, but it appears to be typically between $0.1-200$ parts per million and no sample preparation is needed, making it a quick and easily adaptable technology for automated monitoring or robotic applications. Double-pulsed nanosecond LIBS allows detection of elemental composition in water (Angel et al., 2001). The Army Research Lab and Ocean Optics Inc. are currently collaborating on developing sensors for this technology. Potential uses include the simultaneous measurement of trace metals, nutrients, and dissolved gases, and measurement of chemical odor plumes from marine animals. 
Raman spectroscopy is another technique used to identify and characterize the chemistry and structure of materials in a non-contacting, non-destructive manner. A laser light is shone on a sample; light is scattered, a tiny fraction of which is shifted in frequency as atoms in the material vibrate. Analysis of the frequency shifts (spectrum) of light reveals the characteristic vibration frequencies of the atoms and thus the chemical composition and structure of the sample. Particles as small as $1 \mu \mathrm{m}$ can be identified. Both infrared and Raman vibrational spectroscopy can be combined to provide greater analytical power. Raman spectroscopy may be used to characterize macromolecular structure of organic compounds such as amino acids, lipids and proteins (Angel et al., 1999). Brewer et al. (2004) recently modified and successfully tested a laser Raman Spectrophotometer (DORISS) on gas, liquid, and solid samples in the deep ocean $(3,600 \mathrm{~m})$ using an ROV. Other potential uses include the in situ identification of sea floor minerals and determining the chemical composition of pore water and vent plumes. Currently both LIBS and Raman techniques, coupled with in situ imaging using the VPR, are being developed for plankton and particulate characterization in the ocean (C. Davis, S. Angel, S. Gallager, personal communication). In general, however, these instruments still have significant challenges, requiring miniaturization and lower power consumption for general use in the ocean (Gallager and Whelan, 2004).

Improved spectral deconvolution techniques and model development/interpretation are being used to extract a greater amount of information from multiwavelength ultraviolet/visible transmission spectroscopy (Callahan et al., 2003; Alupoaei et al., 2004). These new analytical techniques allow investigators to differentiate among strains of microorganisms (Fig. 3) and determine their concentration, size, mass, chemical composition, and amount of nucleotides and other chromophores within cells. Initial work has focused on enteric bacteria and protozoans, however, such techniques could be readily transitioned to marine communities since the spectrophotometer instrumentation required is already miniaturized and adapted for use in marine environments (see section on chemical sensing). Multi-frequency and broadband acoustic data are likely amenable to this analytical approach as well.

\section{Major Issues and Recommendations}

A number of workshop reports describe in depth the major issues for sensor development and community recommendations (e.g., Daly, 2000; Seyfried et al., 2000; Gallager and Whelan, 2004). Here, we list some of the issues and briefly summarize the recommendations from those workshops. Common themes included the need to accelerate sensor development given the long time-frames (up to 10 years) to bring sensors to operational status, and the current funding process. We must identify and encourage methods to transition prototype sensors to mass production (possibly through sciencetechnology partnerships and through Small Business Initiative Research programs). The long-term reliability of sensors (stability, accuracy, precision, and internal self-calibration) is essential. Rigorous field validation (confidence in data interpretation) is still needed for most sensors currently in use. The Alliance for Coastal Technologies (ACT) plans to verify performance specifications of essential sensors, starting with some commercially available dissolved oxygen sensors during summer 2004. In addition, standardization is needed for interfacing sensors and sensing systems, for power and communication (modularity, Plug-N-Play issues), and to ensure that future additions of rapidly evolving technologies are compatible. Coherence in sampling volume of multiple sensors and optimized sampling rates are a concern, and

\section{FIGURE 3}

Typical normalized optical density spectra measured from suspensions of Pantoea agglomerans (a surrogate for Y. pestis), Bacillus anthrasis sterne (which is the same organism as anthrax with the lethal factors genetically removed), and Bacillus globigii, a commonly found organism in the same genus as anthrax. All samples analyzed 6 hours after each culture was started. The inset plot is the first derivative of the optical density spectra. (Plot courtesy of L. García-Rubio, USF).

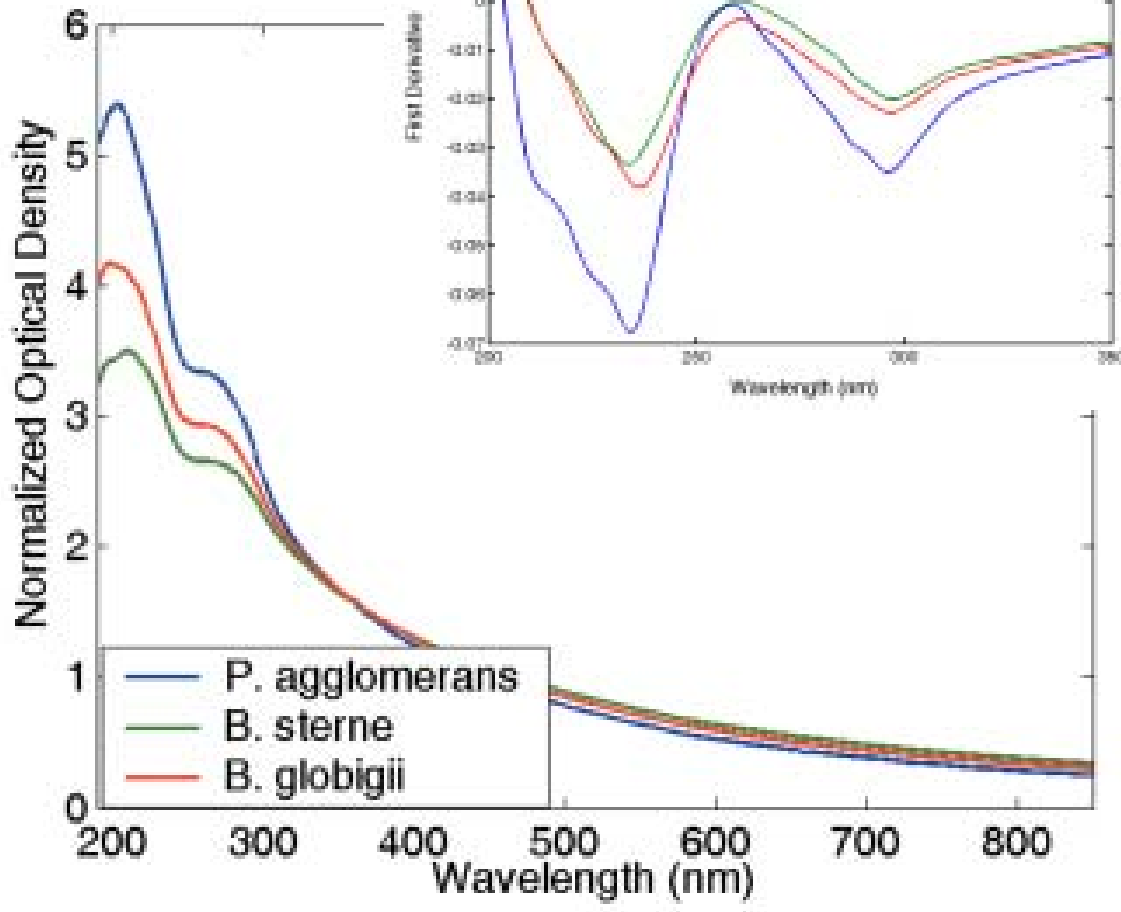


additional efforts are needed in miniaturization of electronics and power packages. Platforms (i.e., profiling moorings, AUVs, gliders, etc.) either require major development (e.g., profiling moorings) or must continue to be improved. Biofouling and corrosion also remain a serious problem in near-surface, benthic, and vent environments. A summary of biofouling issues and current prevention technologies are described in an ACT Workshop Report (2003).

The selection process for sensor development must depend on the science questions, just as the level of accuracy and precision depends on the underlying physical, chemical, and biological phenomenon and associated time and space scales. Recommendations to address the issues listed above include: (1) set up a coordinating committee to advise agencies, sensor developers, and user groups on all issues (inter-sensor comparisons, interface and power hardware and software standards, establish international calibration protocols, performance testing and review), (2) use NASA's rigorous sensor development program as a model for prioritizing development of core and community sensors, (3) establish a failure reporting system like the National Transportation Safety Board, and (4) establish a dedicated instrumentation facility to maintain and calibrate sensors and to support sensor use. The latter would be an important resource for training users, so that a greater number of investigators would have access to sensors and sensor data, encouraging a broader use of sensors. In addition, a workforce must be trained (support personnel, data managers, and repair) following the example of Rutger's new Masters in Operational Oceanography Program. It also was recommended that "smart"sensors, sensing systems, or smart nodes should be developed that can detect natural scales of variability and respond in some pre-programmed way to collect data more intensively during or near the phenomenon of interest. Sensing systems that share common resources (light, detectors, pumps) are needed to collect multivariate environmental data to better interpret phenomena. Another recommendation was to establish more test-bed facilities, especially for high-temperature sensors, and establish an information exchange network for developers and users, which would highlight new funding initiatives and ship-time/deployment opportunities for sensor testing.

\section{Summary}

Despite recent advances, few chemical or biological sensors are ready for long-term ( -1 year) deployment on observatories, even many of those classified as currently operational and commercially available (Development Stage I). Response times of sensors, dynamic range (from eutrophic bay to the open ocean; from the surface to the ocean bottom), sensitivity and detection levels, stability (drift), internal calibrations, storage of reagents, size, power requirements, and biofouling limit the accuracy of results and/ or duration of deployment. Many promising sensors have stated capabilities that are poorly documented, making it difficult to evaluate them. The availability of biological sensors, in particular, is lacking, especially for long deployments. Concerted effort and resources need to be devoted to the continued development of sensors, sensing systems, and sampling systems in order to achieve the full potential of ocean observatories.

\section{Acknowledgements}

We thank Mark Abbott, Michael Callahan, Percy Donaghay, Bill Flanery, Luis García-Rubio, Gwyn Griffiths, Van Holliday, Ken Johnson, Larry Langebrake, Ralph Prien, Tim Short, and Jason Zimmerman for providing advice and help in compiling information. We are also grateful to everyone who contributed information on specific sensors. Lastly, we thank M. Benfield, J. Jaffe, and an anonymous reviewer for providing comments that substantially improved the manuscript. This work was supported by NSF grants OPP0196489 (KLD), OCE-9911037 (MJP), OCE-0118394 (MKT), ONR grants N00014-03-1-0612 (RHB), N00014-0310725 (SMG), and a WHOI Deep Ocean Exploration Institute Fellowship (MKT).

\section{References}

Alliance for Coastal Technologies (ACT). 2003. Biofouling Prevention Technologies for Coastal Sensors/Sensor Platforms. Solomons, Nov. 2003, ACT No. 03-05/UMCES Technical Report Series TS-426-04-CML, www.actonline.ws/Technologies.html.

Alupoaei, C.E., Olivares, J.A. and GarcíaRubio, L.H. 2004. Quantitative spectroscopy analysis of prokaryotic cells: vegetative cells and spores. Biose. Bioelectron. 19:893-903.

Angel, S.M., Carter, J.C., Stratis, D.N., and Marquardt, B.J. 1999. Some new uses for filtered fiber-optic Raman probes: In situ drug identification, and in situ and remote Raman imaging. J Raman Spectrosc. 30:795-805.

Angel, S.M., Stratis, D.N., Eland, K.L., Lai, T., Berg, M.A., and Gould, D.A. 2001. LIBS using dual- and ultra-short laser pulses. Fresen J Anal Chem. 369:320-327.

Atkinson, M.J., Thomas, F., and Larson, N. 1996. Effects of pressure on oxygen sensors. J Atm Ocean Technol. 13:1,267-1,274.

Atkinson, M.J., Thomas, F.I.M., Larson, N., Terrill, E., Morita, K., and Liu, C.C. 1995. A micro-hole potentiostatic oxygen sensor for oceanic CTDs. Deep-Sea Res. I 42:761-771. Baehr, M.M. and DeGrandpre, M.D. 2004. In situ $p \mathrm{CO}_{2}$ and $\mathrm{O}_{2}$ measurements in a lake during turnover and stratification: Observations and modeling. Limnol Oceanogr. 49:330-340.

Bates, N.R., Merlivat, L., Beaumont, L., and Peguignet, C. 2000. Intercomparison of shipboard and moored CARIOCA buoy seawater $\mathrm{fCO}_{2}$ measurements in the Sargasso Sea. Mar Chem. 72:239-255.

Bellerby, R.G.J., Olsen, A., Johannessen, T., and Croot, P. 2002. A high precision spectrophotometric method for on-line shipboard seawater $\mathrm{pH}$ measurements: the automated marine $\mathrm{pH}$ sensor $(\mathrm{AMpS})$. Talanta 56:61-69 
Benfield, M.C., Schwehm, C.J., Fredericks, R.G., Squyres, G., Keenan, S.F., and Trevorrow, M.V. 2003. Measurement of zooplankton distributions with a highresolution digital camera system. In: Strutton, P. and Seuront, L., eds., Scales in Aquatic Ecology: Measurement, Analysis and Simulation. pp. 17-30. CRC Press.

Brewer, P.G., Malby, G., Pasteris, J.D., White, S.N., Peltzer, E.T., Wopenka, B., Freeman, J., and Brown, M.O. 2004. Development of a laser Raman spectrometer for deep-ocean science. Deep-Sea Res. I 51:739-753.

Brierley, A.S., Fernandes, P.G., Brandon, M.A., Armstrong, F., Millard, N.W., McPhail, S.D., Stevenson, P., Pebody, M., Perrett, J., Squires, M., Bone, D.G., and Griffiths, G. 2002. Antarctic krill under sea ice: Elevated abundance in a narrow band just south of the ice edge. Science 295:1,890-1,892.

Byrne, R. H., Kaltenbacher, E.A., and Waterbury, R. 1999. Autonomous in situ analysis of the upper ocean. Sea Tech. 40:71-75.

Byrne, R.H., Liu, X., Kaltanbacher, E.A., and Sell, K. 2002. Spectrophotometric measurement of total inorganic carbon in aqueous solutions using a liquid core waveguide. Anal Chim Acta 451:221-229.

Callahan, M.R., Kaltenbacher, E.A., and Byrne, R.H. 2004. In-situ measurements of $\mathrm{Cu}$ in an estuarine environment using a potable spectrophotometric analysis system. Environ Sci Tech. 38:587-593.

Callahan, M.R., Rose, J.B., and Garcia-Rubio, L. 2003. Use of multiwavelength transmission spectroscopy for the characterization of Cryptosporidium parvum oocysts: Quantitative interpretation. Environ Sci Tech. 37:5, 254-5,261.

Chapin, T. P., Jannasch, H.W., and Johnson, K.S. 2002. In situ osmotic analyzer for the year-long continuous determination of $\mathrm{Fe}$ in hydrothermal systems. Anal Chim Acta 463:265-274.

Chavez, F.P., Wright, D., Herlien, R., Kelley, M., Shane, F., and Strutton, P.G. 2000. A device for protecting moored spectroradiometers from bio-fouling. J Ocean Atmos Tech. 17:215-219.
Chavez, F.P., Strutton, P.G., Friederich, G.E., Feely, R.A., Feldman, G.C., Foley, D.G., and McPhaden, M.J. 1999. Biological and chemical response of the equatorial Pacific Ocean to the 1997-98 El Nino. Science 286:2,126-2,131.

Choi, Y.S., Lvova, L., Shin, J.H., Oh, S.H., Lee, C.S., Kim, B.H., Cha, G.S., and Nam, H. 2002. Determination of oceanic carbon dioxide using a carbonate-selective electrode. Anal Chem. 74:2,435-2,440.

Clark, L. C., Wolf, R., Granger, D., and Taylor, Z., 1953. Continuous recording of blood oxygen tension by polarography. J Appl Physiol. 6:189-193.

Daly, K.L. 2000. Meeting explores sensor technology for remote, interactive aquatic experiments. EOS, Trans Am Geophys Union $81: 580$

Daniel, A., Birot, D., Lehaitre, M., and Poncin, J. 1995a. Characterization and reduction of interferences in flow-injection analysis for the in situ determination of nitrate and nitrite in sea water. Anal Chim Acta 308:413-424.

Daniel, A., Birot, D., Blain, S, Treguer, P., Leilde, B., and Menut, E. 1995b. A submersible flow-injection analyzer for the in-situ determination of nitrite and nitrate in coastal waters. Mar Chem. 51:67- 77.

Davis, C.S., Gallager, S.M., Marra, M., and Stewart, W.K. 1996. Rapid visualization of plankton abundance and taxonomic composition using the video plankton recorder. DeepSea Res. II 43:1,947-1,970.

Davis, C.S., Hu, Q., Gallager, S.M., Tang, X., and Ashjian, C.J. Real-time observation of taxa-specific plankton distributions: An optical sampling method. Mar Ecol Progr Ser., submitted.

DeGrandpre, M.D. 1993. Measurements of seawater $p \mathrm{CO}_{2}$ using a renewable-reagent fiber optic sensor with colorimetric detection. Anal Chem. 65:331- 337.

Degrandpre, M.D. and Baehr, M.M. 1999.

Calibration free optical chemical sensors. Anal Chem. 71:1,152-1,159.
DeGrandpre, M.D., Baehr, M.M., and Hammar, T.R. 2000. Development of an optical chemical sensor for oceanographic applications: The submersible autonomous moored instrument for seawater $\mathrm{CO}_{2}$. In: Chemical Sensors in Oceanography, ed. M.S Vaney. pp. 123-141. Gordon and Breach Publishers.

DeGrandpre, M.D., Hammar, T.R., Smith, S.P., and Sayles, F.L. 1995. In situ measurements of seawater $p \mathrm{CO}_{2}$. Limnol Oceanogr. 40:969-975.

DeGrandpre, M.D., Olbu, G.J., Beatty, C.M., and Hammar, T.R. 2002. Air-sea $\mathrm{CO}_{2}$ fluxes on the US Middle Atlantic Bight. Deep-Sea Res. II 49:4,355-4,367.

Dickey, T.D. and Chang. G.C. 2001. Recent advances and future visions: Temporal variability of optical and bio-optical properties of the ocean. Oceanography 14:15-29.

Ding, K. and Seyfried, W.E. Jr. 1996a. Gold as a hydrogen-sensing electrode for in-situ measurement of dissolved $\mathrm{H}_{2}$ in supercritical aqueous fluids. Geochim Cosmochim Acta 59:1063-1073.

Ding, K. and Seyfried, W.E. Jr. 1996b. Direct $\mathrm{pH}$ measurement of $\mathrm{NaCl}$-bearing fluid with an in situ sensor at $400^{\circ} \mathrm{C}$ and 40 megapascals. Science 272 (5268):1,634-1,636.

Ding, K., Seyfried, W.E. Jr., Tivey, M.K., and Bradley, A.M. 2001. In-Situ measurement of dissolved $\mathrm{H}_{2}$ and $\mathrm{H}_{2} \mathrm{~S}$ in high-temperature hydrothermal vent fluids at the main Endeavour Field, Juan de Fuca Ridge. Earth Planet Sci Lett. 186:417-425.

Ding, K., Seyfried, W.E. Jr., Tivey, M.K., Von Damm, K.L., Bradley, A.M., and Zhang, Z., In-situ $\mathrm{pH}$ measurement of hydrothermal fluids at Mid-ocean ridges, in prep.

Emerson, S., Stump, C., Johnson, B., and Karl, D.M., 2002. In situ determination of oxygen and nitrogen dynamics in the upper ocean. Deep-Sea Res. I 49:941-952.

Fernandez, P.G., Stevenson, P., Brierley, A.S., Armstrong, F., and Simmonds, E.J. 2003. Autonomous underwater vehicles: future platforms for fisheries acoustics. ICES J Mar Sci. 60:684-691. 
Finch, M.S., Hydes, D.J., Clayson, C.H., Weigl, B., Dakin, J., and Gwilliam, P. 1998. A low power ultra violet spectrophotometer for measurements of nitrate in seawater: introduction, calibration and initial sea trials. Anal Chim Acta 377:167 - 177.

Floch, J., Blain, S., Birot, D., and Treguer, P. 1998. In situ determination of silicic acid in sea water based on FIA and colorimetric dualwavelength measurements. Anal Chim Acta 377:157-166.

Franks, P.J.S. and Jaffe, J.S. 2001. Microscale distribution of phytoplankton: initial results from a two-dimensional imaging fluorometer, OSST. Mar Ecol Progr Ser. 220:59-72.

Friederich, G.E., Brewer, P.G., Herlien, R., and Chavez, F.P. 1995. Measurement of sea surface partial pressure of $\mathrm{CO}_{2}$ from a moored buoy. Deep-Sea Res. I 42:1175-1186.

Fries, D.P., Short, R.T., and Byrne, R.H. 2004. Portable underwater mass spectrometer, US Patent No. US6,727,498B2.

Fuchs, E., Jaffe, J.S., Long, R.A., and Azam, F. 2002. Thin laser light sheet microscope for microbial oceanography. Optics Express 10(2):145-154.

Gallager, S.M., and Whelan, J., eds. 2004. The Next Generation of In Situ Biological and Chemical Sensors in the Ocean: A Workshop Report, 85 pp. [www.whoi.edu/institutes/oli/ images/final_report.pdf]

Gallager, S.M.,Yamazaki, H., and Davis, C.S. 2004. The contribution of fine-scale structure and swimming behavior to the formation of plankton layers on Georges Bank. Mar Ecol Progr Series. 267:27-43.

Gamo, T., Sakai, H., Nakayama, E. Ishida, K., and Kimoto, K. 1994. A submersible flow through analyzer for in situ colorimetric measurement down to $2000 \mathrm{~m}$ depth in the ocean. Anal Sci. 10:843-848.

Glazer, B.T., Marsh, A.G., Stierhoff, K. and Luther, III, G.W. 2004. The dynamic response of optical oxygen sensors and voltammetric eletrodes to temporal changes in dissolved oxygen concentrations. Anal Chim Acta. 518:93-100.
Glenn, S.M. and Dickey, T.D. 2003. SCOTS: Scientific Cabled Observatories for Time Series, NSF Ocean Observatories Initiative Workshop Report, Portsmouth VA, 80 pp.

Gordon, H.R., Brown, O.B., and Jacobs, M.M. 1975. Computed relationships between the inherent and apparent optical properties of a flat, homogeneous ocean. App Optics $14: 417-427$.

Gorsky, G., Picheral, M., and Stemmann, L. 2000. Use of the Underwater Video Profiler for the study of aggregate dynamics in the North Mediterranean. Estuar Coast Shelf Sci. 50:121-128.

Graßhoff, K., Kremling, G., and Ehrhardt, M., eds., 1999. Methods of Seawater Analysis. Wiley-VCH, 600 pp.

Griffiths, G., Fielding, S., and Roe, H.S.J. 2002. Biological-physical-acoustic interactions. The Sea 12:441-474.

Gundersen, J.K., Ramsing, N.B., and Glud, N.R. 1998. Predicting the signal of O-2 microsensors from physical dimensions, temperature, salinity, and O-2 concentration. Limnol Oceanogr. 43:1,932-1,937.

Hanson, A.K. and Moore, C. 2001. RealTime Nutrient Surveys in Coastal Waters. Sea Tech. 42:10-14.

Herman, A.W. 1992. Design and calibration of a new optical plankton counter capable of sizing small zooplankton. Deep-Sea Res. Part A. 39(3-4a):395-415.

Heywood, K.J. 1996. Diel vertical migration of zooplankton in the Northeast Atlantic. J Plank Res. 18:163-184.

Holliday D.V., Donaghay, P.L., Greenlaw, C.F., McGehee, D.E., McManus, M.M., Sullivan, J.M., and Miksis, J.L. 2003. Advances in defining fine- and micro-scale pattern in marine plankton. Aquatic Liv Resour. 16:131-136.

Hood, E.M. and Merlivat, L. 1999. Variations of $f \mathrm{CO}_{2}$ and air-sea flux of $\mathrm{CO}_{2}$ in the Greenland Sea gyre using high-frequency time series data from CARIOCA drift buoys. J

Geophys Res. 104:20,571-20,583.
Jaffe, J.S., Ohman, M.D., and De Robertis, A. 1998. OASIS in the sea: measurement of the acoustic reflectivity of zooplankton with concurrent optical imaging. Deep-Sea Res. II 45:1,239-1,253.

Jaffe, J.S., Moore, K.D., McLean, J., and Strand, M.P. 2001. Underwater optical imaging: Status and prospects. Oceanography 14:64-75.

Jahnke, R. ed. 2003. Coastal Observatory Research Arrays: A Framework for Implementation Planning. Coastal Ocean Processes Program (CoOP) Report Number 9, 66 pp.

Jannasch, H., Johnson, K.S., and Sakamoto, C.M. 1994. Submersible, osmotically pumped analyzers for continuous determination of nitrate in situ. Anal Chem. 66:3,352-3,361.

Jannasch, H.W., Wheat, C.G., Plant, J., Kastner, M., and Stakes, D. Continuous chemical monitoring with osmotically pumped water samplers: OsmoSampler design and applications. Limnol Oceanogr., in press.

Jannasch, H.W., Davis, E.E., Kastner, M., Morris, J.D., Pettigrew, T.L., Plant, J.N., Solomon, E.A., Villinger, H.W., and Wheat, C.G. 2003. CORK II: Long-Term monitoring of fluid chemistry, fluxes, and hydrology in instrumented boreholes at the Costa Rica subduction zone. Proc. ODP, Init. Repts. 205: 1-36 [CD-ROM], College Station, TX (Ocean Drilling Program).

Johnson, K.S. and Coletti L.J. 2002. In situ ultraviolet spectrophotometry for high resolution and long term monitoring of nitrate, bromide and bisulfide in the ocean Deep-Sea Res. I 49:1291-1305.

Johnson, K.S., Beehler, C.L., and SakamotoArnold, C.M. 1986. A submersible flow analysis system. Anal Chim Acta 179:245-257.

Joos, F., Stocker, T., Körtzinger, A., and Wallace, D.W.R. 2003. Trends in marine dissolved oxygen: implications for ocean circulation changes and the carbon budget. EOS, Trans Amer Geophys Union 84(21): 197, 201. 
Kadko, D., Tivey, M.K., Bradley, A.M., Sarrazin, J., Butterfield, D., Schultz, A., and Wheat, C.G. 2000. Tidal variability in temperature, flow-rate, and chemistry of diffusely venting fluids in the Main Endeavour Vent Field. EOS, Trans Am Geophys Union 81:F641 [abstract].

Kirkpatrick, G.J., Orrico, C., Moline, M.A., Oliver, M., and Schofield, O.M. 2003.

Continuous hyperspectral absorption measurements of colored dissolved organic material in aquatic systems. Appl Optics 42:6,564-6,568.

Klinkhammer, G.P. 1994. Fiber optic spectrometers for in-situ measurements in the oceans: the ZAPS probe. Mar Chem. 47:13-20.

Le Bris, N., Sarradin, M.-P., Birot, D., and Alasye-Danet, A.-M. 2000. A new chemical analyzer for in situ measurement of nitrate and total sulfide over hydrothermal vent biological communities. Mar Chem. 72:1-15.

Le Bris, N., Sarradin, P.-M., and Pennec, S. 2001. A new deep-sea probe for in situ $\mathrm{pH}$ measurement in the environment of hydrothermal vent biological communities. DeepSea Res. I 48:1,941-1,951.

Lefevre, N., Ciabrini, J.P., Michard, G., Brient, B., DuChaffaut, M., and Merlivat, L. 1993. A new optical sensor for $p \mathrm{CO}_{2}$ measurements in seawater. Mar Chem. 42:189-198.

Lilley, M., Butterfield, D., Kelley, D., Tivey, M.K., Robigou, V., and Delaney, J. 2000. Long and short term variability in hydrothermal activity at the Endeavour RIDGE Observatory site, EOS, Trans Amer Geophys Union 81:628 [abstract].

Lorenzen, C.J. 1966. A method for the continuous measurement if in vivo chlorophyll concentrations. Deep-Sea Res. 13:223-227.

Luther, III, G.W., Reimers, C.E., Nuzzio, D.B. and Lovalvo, D. 1999. In situ development of voltammetric, potentiometric, and amperometric microelectrodes from an ROV to determine $\mathrm{O}_{2}, \mathrm{Mn}, \mathrm{Fe}, \mathrm{S}\left({ }^{-2}\right)$ and $\mathrm{pH}$ in porewaters. Environ Sci Technol. 33:4352-4356.
Luo, T., Kramer, K., Goldgof, D., Hall, L., Samson, S., Remsen, A., and Hopkins, T. 2004. Recognizing plankton images from the Shadow Image Particle Profiling Evaluation Recorder. IEEE Transactions on Systems, Man, and Cybernetics. Part B. Vol. 34(4), in press.

Martz, T.R., Carr, J.J., French, C.R., and DeGrandpre, M.D. 2003. A submersible autonomous sensor for spectrophotometric $\mathrm{pH}$ measurements of natural waters. Anal Chem. $75: 1,844-1,850$.

Masserini, R.T., Jr. and Fanning, K.A. 2000.

A sensor package for the simultaneous determination of nanmolar concentrations of nitrite, nitrate, and ammonia in seawater by fluorescence detection. Mar Chem. 68:323-333.

Massoth, G. J. and Milburn. H.B. 1997. SUAVE (Submersible System Used to Assess Vented Emissions): a diverse tool to probe the submarine hydrothermal environment, Proceedings of Marc'h mor Workshop, IUEM Brest, pp. 80-87.

McDonald, M.A., Webb, S.C., and Hildebrand, J.A. 1995. Blue and fin whales observed on a seafloor array in the Northeast Pacific. J Acous Soc Am. 98(2), Pt. 1:712-721.

McGillicuddy, Jr., D.J., Robinson, A.R., Siegel, D.A., Jannasch, H.W., Johnson, R., Dickey, T.D., McNeil, J., Michaels, A.F., and Knap, A.H. 1998. Influence of mesoscale eddies on new production in the Sargasso Sea. Nature 394:263-266.

McMurtry, G. M. and Smith, S.J. 2001. Mass SURFER: a low-power underwater mass spectrometer for monitoring dissolved gas, solutes and large organic compounds. In: Proceed. Oceans 2001. pp. 259-263. Marine Tech. Soc. and IEEE, Honolulu.

Nakamura, K., Veirs, S., Sarason, C.P., McDuff, R.E., Stahr, F., Yoerger, DR., and Bradley, A.M. 2000. Electrochemical signals in rising buoyant plumes and tidally oscillating plumes at the Main Endeavour Field, Juan de Fuca Ridge, EOS, Trans Am Geophys Union. 81:F628 [abstract].
National Research Council Report. 2003. Enabling Ocean Research in the $21^{\text {st }}$ Century: Implementation of a Network of Ocean Observatories. 195 pp. Washington, D.C.: National Academy of Sciences Press.

Owens, W.B. and Millard, R.C., Jr. 1985. A new algorithm for CTD oxygen calibration. J Phys. Oceanogr. 15:621-631

Prien, R.D. and Hydes, D.J. 2003. A full ocean depth UV-spectrophotometer for nitrate measurements. OCEANS 2003 - 22-26 September 2003 - San Diego, California, USA.

Radford-Knoery, J., Baker, E., Charlou, J.-L., Donval, J.-P., Fouquet, Y., German, C.R., and Massoth, G.J. 1997. Hydrothermal plume traced by dissolved sulfide. Proceedings of Marc'h mor Workshop, IUEM Brest, pp.165-168.

Remson, A., Hopkins, T.L., and Samson, S. 2004. What you see is not what you catch: a comparison of concurrently collected net, Optical plankton Counter, and Shadowed Image Particle Profiling Evaluation Recorder data from the northeast Gulf of Mexico. DeepSea Res. I 51:129-151.

Reysenbach, A.-L., Longnecker, K., and Kirshtein, J. 2000. Novel bacterial and archaeal lineages from an in-situ growth chamber deployed at a Mid-Atlantic Ridge Hydrothermal vent. Appl Environ Microbiol. 66:3,798-3,806.

Robert-Baldo, G.L., Morris, M.J., and R.H. Byrne. 1985. Spectrophotometric determination of seawater $\mathrm{pH}$ using phenol red. Anal Chem. 57:2,564-2,567.

Rudnik, D.L. and Perry, M.J., eds. 2003. Autonomous and Lagrangian Platforms and Sensors, Workshop Report, 64 pp., www.geoprose.com/ALPS.

Samson, S., Hopkins, T., Remson, A., Langebrake, L., Sutten, T., and Patten, J. 2001. A system for high-resolution zooplankton imaging. IEEE J Ocean Eng. 26:671-676. 
Scholin, C., Massion, G., Mellinger, E., Brown, M., Wright, D., and Cline, D. 1998. The development and application of molecular probes and novel instrumentation for detection of harmful algae. Ocean Community Conference '98 Proceedings, Vol. 1. pp. 367370. Marine Technology Society.

Seyfried, W.E., Johnson, K.S., and Tivey, M.K. 2000. In-Situ Sensors: Their Development and Application for the Study of Chemical, Physical and Biologic Systems at Mid-Ocean Ridges. RIDGE Workshop Report, 58 pp.

Short, R.T., Fries, D.P., Toler, S.K., Lembke, C.E., and Byrne, R.H. 1999. Development of an underwater mass spectrometry system for in-situ chemical analysis. Meas Sci

Technol.10:1195-1202.

Short, R.T., Fries, D.P., Kerr, M.L., Lembke, C.E., Toler, S.K., Wenner, P.G., and Byrne, R.H. 2001. Underwater mass spectrometers for in-situ chemical analysis of the hydrosphere. J Am Soc Mass Spectrom. 12:676-682.

Smith, M.C., Casper, E.T., Farmer, A.S., Fries, D.P., and Paul, J. 2004. Towards autonomous in situ microbial monitoring - The Autonomous Microbial Genosensor (AMG). Ocean Research Conference, 15-20 February, Honolulu, Hawaii.

Steimle, E.T., Kaltenbacher, E.A., and Byrne, R.H. 2002. In-situ nitrate measurements using a compact spectrophotometric analysis system. Mar Chem. 77:255-262.

Tabacco, M.B., Uttamlal, M., McAllister, M., and Walt, D.R. 1999. An autonomous sensor and telemetry system for low-level $p \mathrm{CO}_{2}$ measurements in seawater. Anal Chem. 71:154-161.

Tang, X., Stewart, W.K., Huang, H., Gallager, S.M., Davis, C.S., Vincent, L., and Marra, M. 1998. Automated plankton image recognition. Artificial Intelligence Rev. 12:177-199.

Tang, X., Lin, F., Samson, S., and Remsen, A. Binary Plankton Image Classification. IEEE J Ocean Eng., in press.
Tapp, M., Hunter, K., Currie, K., and Mackaskill, B. 2000. Apparatus for continuousflow underway spectrophotometric measurement of surface water $\mathrm{pH}$. Mar Chem. 72:193-202.

Tivey, M.K., Stakes, D.S., Bradley, A., Seewald, J., Wheat, C.G., Reysenbach, A.-L., Page, A,. Koski, R.A., and Leg 2 GOC Scientific Party. 2003. Use of thermocouple arrays to investigate the environment within actively forming chimney deposits, Guaymas Basin, EOS, Trans Amer Geophys Union, 84(46), Fall Meet. Suppl., Abstract OS32A0233, F827.

Voegeli, F.A., Smale, M.J., Webber, D.M., Andrade, Y., and O'Dor, R.K. 2001. Ultrasonic telemetry, tracking and automated monitoring technology for sharks. Environ Biol Fishes 60:267-281.

Wang, W., Reimers, C.E., Wainright, S.C., Shahriari. M.R., and Morris, M.J. 1999. Applying fiber-optic sensors for monitoring dissolved oxygen. Sea Tech. 40(3):69.

Weeks, D.A. and Johnson, K.S. 1996. Solenoid pumps for flow injection analysis. Anal Chem. 68:2,717-2,719.

Wenner, P.G., Bell, R.J., van Amerom, F.H.W., Toler, S.K., Edkins, J.E., Hall, M.L., Koehn, K., Short, R.T., and Byrne, R.H. 2004. Environmental chemical mapping using an underwater mass spectrometer. Trends in Anal Chem., in press.

Wheat, C.G., Jannasch, H.W., Kastner, M., Plant, J.N., and DeCarlo, E.H. 2003. Seawater transport and reaction in upper oceanic basaltic basement: Chemical data from continuous monitoring of sealed boreholes in a mid-ocean ridge flank environment. Earth Planet Sci Lett. 216:549-564.

Wheat, C. G., Jannasch, H.W., Plant, J.N., Moyer, C.L., Sansone, F.J., and McMurtry, G.M. 2000. Continuous sampling of hydrothermal fluids from Loihi Seamount after the 1996 event. J Geophys Res. 105:19,353-19,368.
White, S.N., Chave, A.D., and Reynolds, G.T. 2002. Investigations of ambient light emission at deep-sea hydrothermal vents, J Geophys Res. 107 (B1):10.1029/2000JB000015.

Wiebe, P.H. and Benfield, M.C. 2003. From the Henson net toward four-dimensional biological oceanography. Progr Oceanogr. 56:7-136.

Wiebe, P.H., Prada, K.E., Austin, T.C., Stanton, T.K., and Dawson, J.J. 1995. New tool for bioacoustical oceanography. Sea Tech. 36:10-14.

Woodd-Walker, R.S., Gallienne, C.P., and Robins, D.B. 2000. A test model for optical plankton counter (OPC) coincidence and a comparison of OPC-derived and conventional measures of plankton abundance. J Plank Res. 22:473-483.

Zhang, X., Roman, M., Sanford, A., Adolf, H., Lascara, C., and Burgett, R. 2000. Can an optical plankton counter produce reasonable estimates of zooplankton abundance and biovolume in water with high detritus? J Plank Res. 22:137-150.

Zhou, M. and Tande, K., ed. 2002. Optical Plankton Counter Workshop. GLOBEC Report No. 17, 17-20 June 2001, Tromso, Norway.

Zhou, M. and Dorland, R.D. Aggregation and vertical migration behavior of Euphausia superba. Deep-Sea Res., in press. 